\title{
MULTI-SCALE ANALYSIS ON THE INFLUENCE OF MOISTURE ON THE MECHANICAL BEHAVIOR OF FERRUGINOUS SANDSTONE.
}

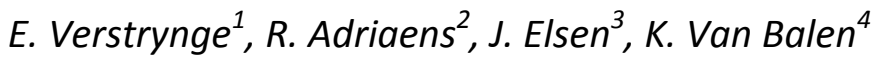

This is the preprint of a paper published as: Verstrynge, E., Adriaens, R., Elsen, J., Van Balen, K. (2014). "Multi-scale analysis on the influence of moisture on the mechanical behavior of ferruginous sandstone". Construction \& Building Materials, 54, 78-90: 2014

Original Paper DOI: 10.1016/j.conbuildmat.2013.12.024

\begin{abstract}
Moisture is known to decrease the mechanical properties of brittle construction materials. The present study focuses on the influence of moisture on the mechanical behavior of ferruginous sandstone in order to understand and quantify this effect. The investigated Diestian and Brusselian ferruginous sandstone has frequently been applied in monumental constructions and many of these monuments presently suffer from material degradation and, in some cases, stability concerns. Experimental analysis is performed on different levels, from micro to macro behavior, in order to obtain a more detailed picture of the acting processes. Therefore, a methodology is proposed which combines established as well as advanced experimental techniques, involving non-destructive testing for pre-classification of the sandstone's quality, mineralogical analysis and investigation of mechanical properties under dry and saturated conditions. It was observed that the decrease of mechanical properties, such as strength and stiffness, is more pronounced for lower-quality ferruginous sandstone. It was also found that water adsorption by the sandstone during acoustic emission-controlled creep tests shifts the specimen's behavior from meta-stable creep damage to accelerated failure. These observations were linked to the results of the mineralogical study, in which the consolidation degree and clay content were analyzed and to the results of the microfocus computed tomography which visualized the fracture progress on a micro scale.
\end{abstract}

Keywords: multi-scale experimental testing, ferruginous sandstone, mechanical behavior, moisture, microfocus computed tomography, ultrasonic testing, quantitative XRD, AE-controlled creep tests

\footnotetext{
${ }^{1}$ Dr. ir.-arch., KU Leuven, Civil Engineering Department, Building Materials and Building Technology division, els.verstrynge@bwk.kuleuven.be

${ }^{2}$ KU Leuven, Department of Earth and Environmental Sciences, Division of geology, rieko.adriaens@ees.kuleuven.be

${ }^{3}$ Prof. Dr., KU Leuven, Department of Earth and Environmental Sciences, Division of geology, jan.elsen@ees.kuleuven.be

${ }^{4}$ Prof. Dr. ir.-arch., KU Leuven, Civil Engineering Department, Building Materials and Building Technology division,

koenraad.vanbalen@bwk.kuleuven.be
} 


\section{Introduction}

Moisture is known to have a negative effect on the mechanical properties, long-term behavior and overall durability of clay brick and natural stone masonry. These effects are due to weathering, erosion, freeze-thaw cycling, chemical and physico-chemical degradation and instigation of biological degradation. Moisture also has a direct impact on the short- and long-term mechanical characteristics of porous building materials, such as a reduction of strength and stiffness properties. However, a detailed quantification and comprehension of the acting processes in strength and stiffness reduction has not yet been achieved in a civil engineering context. Therefore, the present study focuses specifically on the influence of moisture on the mechanical behavior of ferruginous sandstone in order to understand and quantify this effect by means of a multi-scale experimental investigation.

Ferruginous sandstone does not contain lime but has a ferruginous binder, causing its typical red-brown color. In this study, ferruginous sandstone from two different formations will be analyzed. The first one, 'Diestian' ferruginous sandstone is the typical building stone of the Hageland (North-East Belgium) and was widely used at the height of the economic and demographic expansion in the 14th to 16th century. All emblematic gothic monuments of the region were constructed in this material. Its limited capacity for sculpturing led to a local variant of the Gothic style, known as 'Demer Gothic' [1, 2]. Weathering processes often cause decay and material loss in Diestian ferruginous sandstone, see Fig. 1. In addition, this sandstone has a relatively low average strength and a large scatter on its strength and stiffness properties. Long-term mechanical deterioration under elevated constant load levels (such as the weight of a tower) can give cause to important deformations and crack growth [3]. It is known that ferruginous sandstone is vulnerable to the process of time-dependent deformation increase under constant loading, which is referred to as creep damage $[4,5]$.

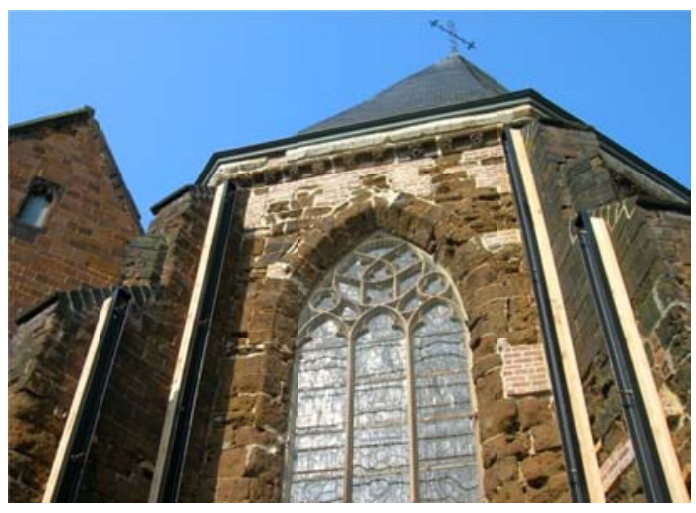

Fig. 1. Severely weathered Diestian ferruginous sandstone with stone replacements made in clay bricks (choir section of the St. Eustachius church at Zichem, Belgium).

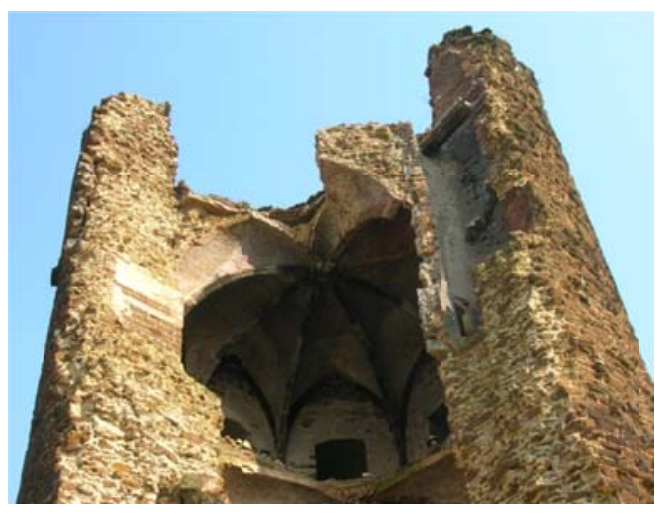

Fig. 2. Maagden tower at Zichem (Belgium), after its partial collapse in 2006. 
Aim of these investigations is to assess the contribution of moisture ingress to the collapse of two historical structures which were constructed in Diestian ferruginous sandstone, see example in Fig. 2 [4]. It is important to notice that, although the described experimental framework was applied on a specific type of ferruginous sandstone, the methodology and general conclusions are more widely applicable on low and medium strength natural stone and masonry.

In the present study, the characteristics of Diestian ferruginous sandstone will be compared with 'Brusselian' ferruginous sandstone. The latter was exploited and commonly used in the region south of Brussels. Brusselian ferruginous sandstone has a gray-brown to brown-orange color with a purple shine. The Brusselian type ferruginous sandstone contains much less glauconite compared to Diestian sandstone and is less heterogeneous. It appears to have a higher average strength and be more durable, and it is still more available, reasons why Brusselian sandstone is often applied as a replacement stone for Diestian sandstone.

Since replacement stones of Diestian ferruginous sandstone are very scarce, only a limited amount of test material was available for this research, resulting in a very limited number of test specimens.

Therefore, a comprehensive statistical analysis is not the object of this study. A qualitative analysis was performed, linking the results of different types of non-destructive and destructive tests on selected test samples. Therefore, a methodology is proposed which combines established as well as advanced experimental techniques, involving non-destructive testing (NDT), mineralogical analysis and investigation of mechanical properties. Such multi-scale experimental analysis leads to advanced insight in the mechanical behavior of dry and saturated sandstone samples. It enables a detailed study of the influence of moisture ingress, even if the number of specimens is restricted. A second aim is to bridge the gap between fundamental research and practical, on-site application and durability assessment.

The setup and results of these experimental procedures will be discussed and related to each other. Firstly, a literature review is given on the influence of moisture on mechanical properties of porous building materials. The theoretical background and some of the experimental procedures applied in this study were developed in rock mechanics or geological studies. Therefore, these research domains will provide an important background for the presented study.

\section{The influence of moisture on mechanical properties}

Increasing the water content in porous building materials, such as bricks and natural stones, causes a decrease in strength and stiffness properties $[6,7]$. To acknowledge the fact that the compressive strength of bricks decreases in wet conditions, the European code EN 772-1 provides a conversion factor. To normalize test results and obtain a value for the air-dry compressive strength of the bricks, obtained strength values should be increased or decreased with $20 \%$ for specimens immersed in water or stored at oven-dry conditions respectively.

The strength reduction in (partially) saturated porous building materials can be due to a decrease in capillary tension, increase in pore pressure, reduction of the fracture surface energy, reduction of 
internal friction and chemical deterioration. These effects have been widely studied in rock mechanics and a number of these mechanisms may be acting at the same time [8-10]. Specifically for ferruginous sandstone, chemical reactions under contact with water might cause ferruginous depositions and lead to a reduction of the fracture surface energy. Erguler and Ulusay presented a comprehensive experimental study which demonstrated the reduction of strength and stiffness of clay-bearing rock under different saturation levels [11]. Ferruginous sandstone often contains a certain fraction of clay minerals, which might swell due to absorption of water within their sheet-like structure, causing a decrease in internal friction and a less stable micro-structure. Therefore, a study of the clay content of the sandstones will be part of the mineralogical analysis.

In addition to the impact on the material's strength and stiffness, the moisture content also influences the long-term strength properties, which are reflected in time-dependent creep deformations. The factors which have the largest influence on the extent of time-dependent deformations under constant stresses are the relative stress level, the stiffness properties, moisture and temperature, although the influence of the latter is very limited within normal conditions. The relative stress level, calculated as ratio between the absolute stress and the compressive strength, is seen as the major driving force behind the creep phenomenon [5, 12]. There is no conclusive evidence that creep deformations depend on the relative humidity level if the specimen is in hygral equilibrium with its surroundings [13].

However, humidity variations largely influence the creep deformations as they cause moisture transport [5]. An increase in water content also results in a strength reduction and thus increases the relative stress level. To investigate the influence of moisture on time-dependent creep deformations, creep tests are included in the experimental program described below.

\section{Overview of the experimental program}

\section{Material}

Table 1 presents the range of characteristics of Diestian and Brusselian ferruginous sandstone, as found in literature. It can be observed that both types of ferruginous sandstone have a relatively high porosity and especially Diestian sandstone has a relatively low compressive strength and very heterogeneous material properties. This heterogeneity is present when comparing two different building blocks, but also within one block and is due to the layered structure of the deposition sites and the inhomogeneous distribution of pores, grains and minerals. Within one block, the stratification and its effect on strength and stiffness properties is usually negligible or limited and not visually observable.

It has to be taken into account that the values of Diestian sandstone result from 5 experimental test programs, with a total of 145 specimens applied for the compressive tests, while the range indicated for Brusselian sandstone originates from 3 studies with only 15 tested specimens. This results in a larger range for Diestian ferruginous sandstone from a statistical point of view, however, a larger scatter in quality and deterioration degree is also found when investigating this sandstone type on site at historical monuments. 


\begin{tabular}{|l|c|c|}
\hline property & Diestian ferruginous sandstone & Brusselian ferruginous sandstone \\
\hline Compressive strength $[\mathrm{MPa}]$ & $1.5-40$ & $9-15$ \\
\hline Porosity $[\%]$ & $22-45$ & $21-30$ \\
\hline Density $\left[\mathrm{kg} / \mathrm{m}^{3}\right]$ & $1430-2410$ & $1880-2800$ \\
\hline
\end{tabular}

Table 1: Range of material characteristics of two types of ferruginous sandstone, as found in literature $[2,5,14]$ and internal reports (in Dutch).

Due to the high scatter on strength properties, not all specimens of Diestian ferruginous sandstone could be considered as the same material during experimental testing. Therefore, a distinction was made between "high" and "low" quality Diestian ferruginous sandstone. The initial strength classification was performed, based on visual aspects: a higher quality Diestian ferruginous sandstone will show a darker and more homogeneous color, less material loss upon wetting or rubbing, better sorting and smaller average grain size, less porosity and a limited amount of large macro-pores. This initial visual classification was confirmed and detailed during the experimental testing. The distinction between "high" and "low" quality ferruginous sandstone is obviously subjective and very rough as it disregards stones with "medium" quality. To make a clear distinction and facilitate the interpretation of test results, only samples with distinct good or bad quality were chosen for experimental testing. However, the classification is necessary as test results could not be averaged over the complete range of qualities, since scatter on the material properties and mechanical behavior is too large. Fig. 3 presents two representative test specimens of Diestian ferruginous sandstone. The difference in quality between both test samples can be visually distinguished.

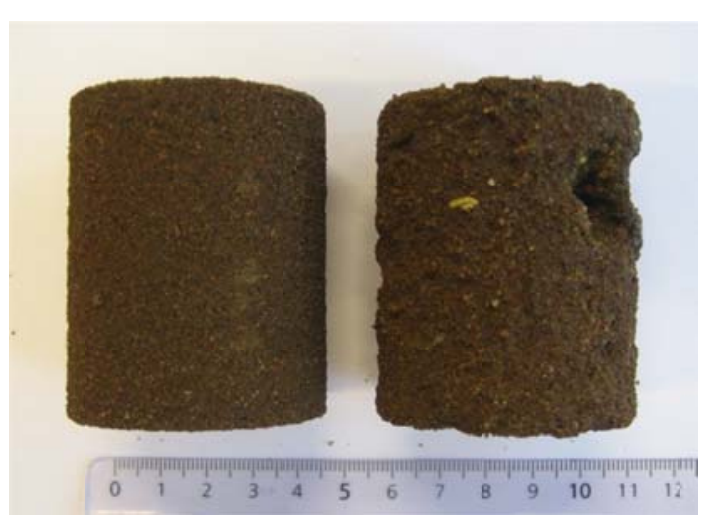

Fig. 3. Test sample of "high" (left) and "low" (right) quality Diestian ferruginous sandstone. 


\section{Test program}

A test methodology is proposed which combines established as well as advanced experimental techniques, involving non-destructive testing (NDT), mineralogical analysis and investigation of mechanical properties. The non-destructive tests include determination of porosity, apparent density and ultrasonic tests in dry and wet conditions. They aim at a more detailed classification of the test samples after a first visual inspection. The results of the non-destructive tests also provide background information and suggest possibilities for on-site quality assessment of ferruginous sandstone. The mineralogical analysis includes X-Ray Diffraction (XRD) and petrographic analysis on thin sections to establish the mineralogical composition of the samples. The destructive mechanical testing involves compressive tests, Acoustic Emission (AE) -controlled creep tests and X-ray microfocus Computed Tomography (microCT) at different load levels, including dry and wet samples and focusing on the influence of moisture on the observed micro- and macroscopic mechanical behavior.

A schematic overview of the experimental program is presented in Fig. 4. To obtain as much relevant information as possible from one sample and to correlate information retrieved from different tests, a rational chronological order as shown in the scheme should be followed.

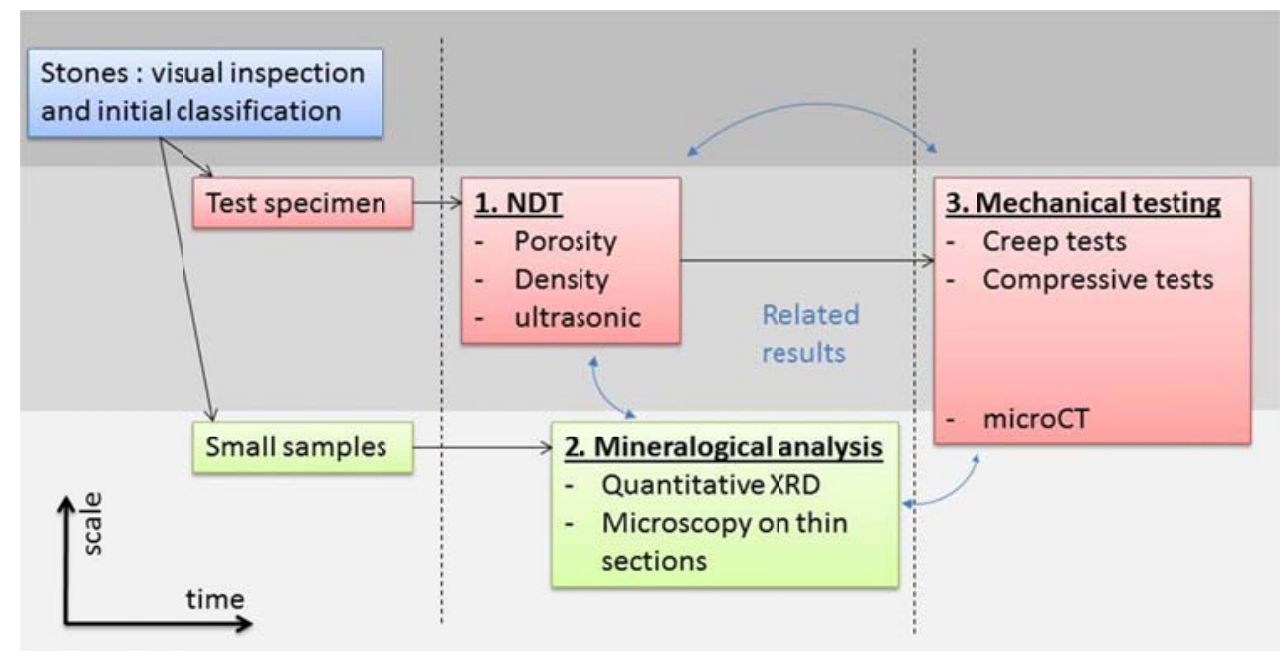

Fig. 4. Scheme of methodology of multi-scale experimental analysis

\section{Test specimens}

The Diestian ferruginous sandstone samples in the present research originate from the collapsed bell tower of the Sint-Willibrordus church at Meldert [4]. The Brusselian sandstone was obtained from a contractor who applied it as replacement stone for Diestian sandstone.

The cylindrical specimens had a diameter of $50 \mathrm{~mm}$ and height of $60 \mathrm{~mm}$ for the non-destructive tests and compressive tests and a diameter of $80 \mathrm{~mm}$ and height $100-140 \mathrm{~mm}$ for the creep tests. The 
remainders of the specimens' ends after core drilling and surface leveling were used for mineralogical analysis. Additional samples (diameter $10 \mathrm{~mm}$, height $15 \mathrm{~mm}$ ) were made from the same source stones for X-ray microfocus computed tomography.

Samples which were tested in "dry" conditions were stored at $20^{\circ} \mathrm{C}$ and $60 \% \mathrm{RH}$ until constant weight. For the determination of open porosity and apparent density, the samples were saturated under vacuum according to relevant standards (see Section 4.1). For the ultrasonic tests and mechanical testing, "saturated" samples were submerged in water at $20{ }^{\circ} \mathrm{C}$ under environmental pressure for 30 minutes after which in average 60,42 and $65 \%$ of the water uptake under vacuum was achieved for low and high quality Diestian ferruginous sandstone and for Brusselian ferruginous sandstone respectively, see Fig. 5. It is not clear at this point what is the cause for the lower value obtained for high quality Diestian sandstone, although it might be related to its pore size distribution. The amount of water retained in the samples after a submersion of 30 minutes is in average $94 \%$ of the amount obtained after a 24 hour submersion under the same conditions. Although the test samples are thus "partly saturated", they will be referred to as "saturated" since a high saturation degree was obtained after only 30 minutes.

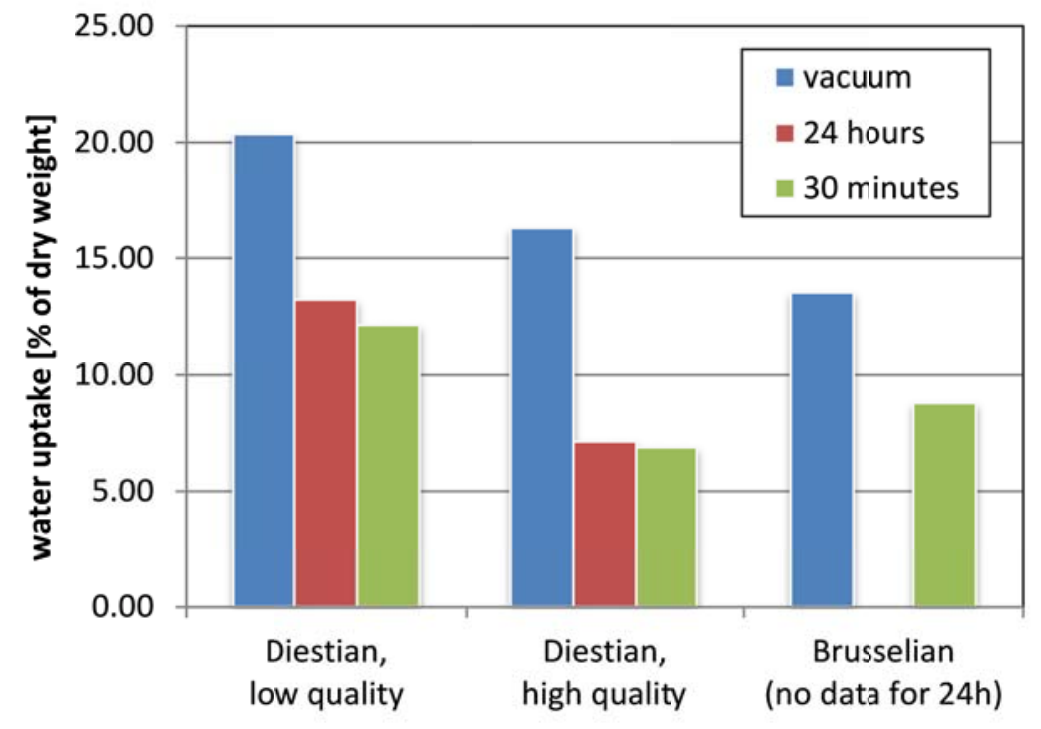

Fig. 5. Comparison of saturation degree obtained under vacuum and under environmental pressure after 24 hours and 30 minutes. 


\section{Multi-scale analysis}

\subsection{Non Destructive Testing (NDT)}

Aim of the non-destructive tests is to give a more detailed impression of the sandstone's quality, in addition to the visual classification discussed above. The apparent density and porosity were determined, as they are strongly related to the material's strength. Ultrasonic wave velocities were determined in dry and saturated tests specimens. The latter technique can easily be applied on-site, however, no detailed database currently exists relating the ferruginous sandstone's quality and the moisture content with the ultrasonic wave velocity.

\section{Porosity and apparent density}

The open porosity and apparent density were determined according to NBN EN 1936: 2007 by saturation under vacuum. In a second method, the density from mass/volume ratio was determined by weighing the dry samples on a balance and calculating their geometric volume. The low quality Diestian ferruginous sandstone samples contained very large open pores (see Fig. 3), which are not subtracted when calculating the geometric volume. Thus in case of low quality sandstone, the mass/volume ratio is lower than the apparent density, see Table 2. For the other two sandstone types, the average density values as determined by the two different methods is similar.

It can be observed that the low quality Diestian ferruginous sandstone has very high porosity and low apparent density. The higher quality Diestian ferruginous sandstone has similar apparent density compared to the Brusselian ferruginous sandstone, but its open porosity value is still large.

\begin{tabular}{|l|c|c|c|}
\hline & $\begin{array}{l}\text { Low quality Diestian } \\
\text { ferruginous sandstone }\end{array}$ & $\begin{array}{l}\text { High quality Diestian } \\
\text { ferruginous sandstone }\end{array}$ & $\begin{array}{l}\text { Brusselian ferruginous } \\
\text { sandstone }\end{array}$ \\
\hline $\begin{array}{l}\text { Porosity } \\
\text { [vol. \%] }\end{array}$ & $36.3(\# 6,5.8 \%)$ & $31.7(\# 3)$ & $21.7(\# 2)$ \\
\hline $\begin{array}{l}\text { Apparent density } \\
{\left[\mathrm{kg} / \mathrm{m}^{3}\right]}\end{array}$ & $1791(\# 6,3.1 \%)$ & $1945(\# 3)$ & $1960(\# 2)$ \\
\hline $\begin{array}{l}\text { Density from } \\
\text { mass/volume ratio }\left[\mathrm{kg} / \mathrm{m}^{3}\right]\end{array}$ & $1602(\# 10,5.4 \%)$ & $1949(\# 5,7.1 \%)$ & $1976(\# 6,2.2 \%)$ \\
\hline
\end{tabular}

Table 2: Porosity and density of different types of ferruginous sandstone. Values are indicated with average (\#number of samples, coefficient of variation in \% in case of an adequate number of samples).

\section{Ultrasonic tests and moisture influence on wave attenuation}

Ultrasonic pulse velocities (UPV) were measured with two $55 \mathrm{kHz}$ sensors in a direct setup, with the two sensors positioned on each end of the cylindrical sample parallel to the cylinder's axis. Other possible setups are semi-direct (sensors on two adjacent sides) and indirect (sensors on the same side). Since the ultrasonic wave velocity is related to the density and elastic bulk modulus of the material, ultrasonic testing is often used for characterization of concrete and natural stones [15-18]. 
Before coring of the cylindrical specimens, an ultrasonic test was performed on the sandstone blocks (10 $\times 10 \times 20 \mathrm{~cm}^{3}$ ), see Table 3. The values obtained from these initial measurements are higher than those obtained from the test samples, which might be due to size effects. With an average wave velocity of $1800-2740 \mathrm{~m} / \mathrm{s}$ and a frequency of $55 \mathrm{kHz}$, average wave lengths of 3-5 cm are expected which is in the same order of magnitude as the size of the small test samples.

It can be observed from Table 3 that a higher ultrasonic pulse velocity is related to a better quality ferruginous sandstone. It can also be noticed that the saturated samples show lower wave velocities compared to the dry samples. This effect is more pronounced for the lower quality ferruginous sandstone as can also be observed from Fig. 6 , which presents the wave velocities for all samples in dry and saturated conditions.

\begin{tabular}{|l|c|c|c|}
\hline $\begin{array}{l}\text { Ultrasonic pulse velocity } \\
{[\mathrm{m} / \mathrm{s}]}\end{array}$ & $\begin{array}{c}\text { Low quality Diestian } \\
\text { ferruginous sandstone }\end{array}$ & $\begin{array}{c}\text { High quality Diestian } \\
\text { ferruginous sandstone }\end{array}$ & $\begin{array}{c}\text { Brusselian ferruginous } \\
\text { sandstone }\end{array}$ \\
\hline Large stone blocks & $1799(\# 1)$ & $2374(\# 1)$ & $2740(\# 2)$ \\
\hline $\begin{array}{l}\text { Small test specimen }- \\
\text { dry }\end{array}$ & $1109(\# 6,17.4 \%)$ & $1306(\# 2)$ & $1646(\# 6,11.2 \%)$ \\
\hline $\begin{array}{l}\text { Small test specimen - } \\
\text { saturated }\end{array}$ & $925(\# 6,28.6 \%)$ & $1163(\# 2)$ & $1632(\# 6,11.6 \%)$ \\
\hline
\end{tabular}

Table 3: Results of ultrasonic pulse velocity testing on different types of ferruginous sandstone. Values are indicated with average (\#number of samples, coefficient of variation in \% in case of an adequate number of samples).

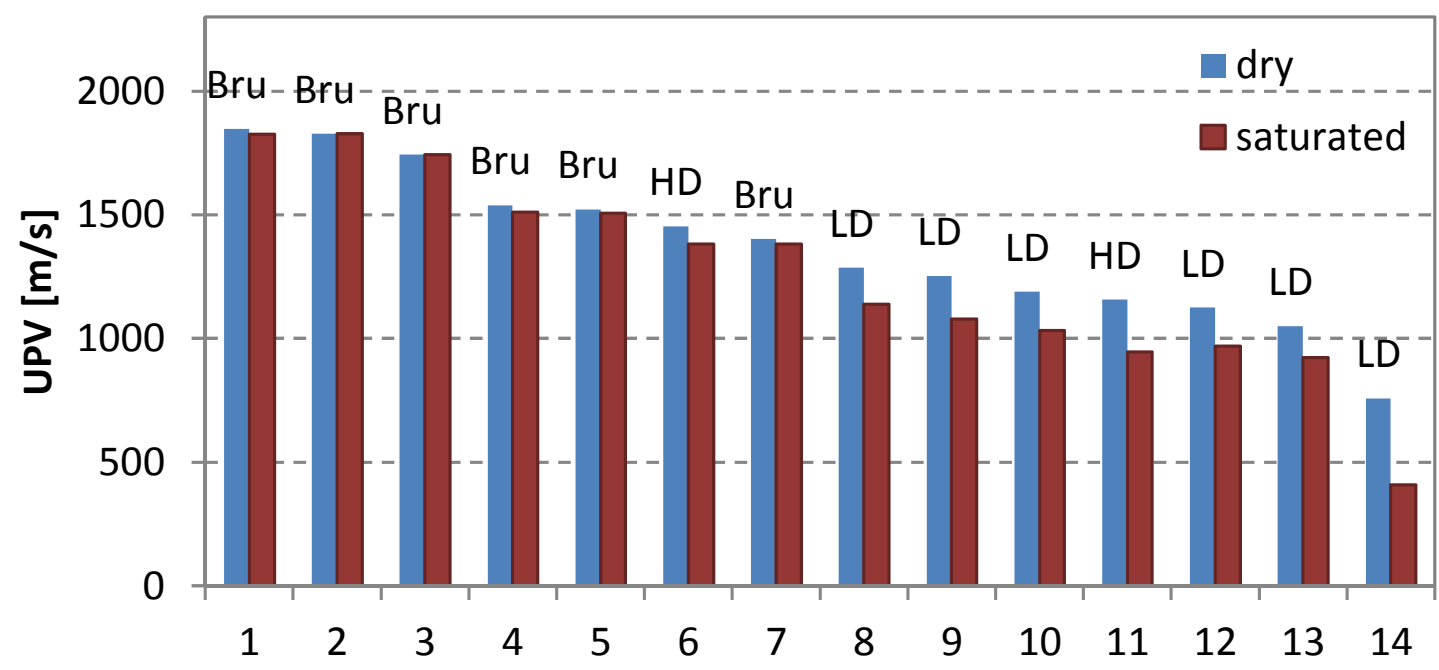

Fig. 6. Comparison of ultrasonic pulse velocity (UPV) of ferruginous sandstone samples in dry and saturated conditions (Bru = Brusselian, LD = low quality Diestian, HD = high quality Diestian sandstone). 
A different effect of moisture on the ultrasonic pulse velocity is usually observed for concrete $[17,19]$ and natural stones with low porosity, namely an UPV increase upon saturation. Such increase in UPV in wet samples was observed for granite [18] and marble [20]. Bellopede and Manfredotti observed increased as well as decreased ultrasonic pulse velocities for saturated limestone samples, as well as decreased wave velocities in a saturated clay-containing sandstone [20], which is in accordance with the results obtained above.

In case of the investigated ferruginous sandstone with medium to high porosity, the decrease in wave velocity is likely due to an important increase in density upon moisture saturation. In saturated conditions, the compressibility will decrease and thus the bulk modulus will increase. The wave velocity is related to the ratio between bulk modulus and density and a marked increase in density might counteract the increase in bulk modulus and result in a velocity decrease. The increase or decrease of bulk wave velocities upon saturation thus depends on the ratio between bulk modulus and density change. It should however be clear that this explanation is a simplification, since the influence of moisture on the ultrasonic wave propagation is affected by the overall porosity, but also by the pore size distribution, pore shape, grain size distribution and mineralogy of the sample [21].

A second aspect to be investigated is the wave attenuation, which is the loss in wave energy (in dB) per unit propagation distance and can be presented as the slope of the maximum detected wave amplitude in function of the distance between source and receiver [22]. Also the wave attenuation within the material will be influenced by the moisture content of the samples due to fluid-related dispersion and this phenomenon is frequency-dependent $[21,23]$. Fig. 7 presents an attenuation profile for high quality Diestian ferruginous sandstone under different moisture conditions. Tests were carried out with two $150 \mathrm{kHz}$ resonance PZT sensors in an indirect setup. It can be observed that the water content has a negative influence on the signal propagation. No distinct difference in attenuation profile is found for specimens stored at relative humidity levels of 22-85-92 \% until constant weight. For the specimens submerged in water for 30 minutes before testing, an increase in signal attenuation and a decrease in detectable source-sensor distance are observed, see Fig. 7.

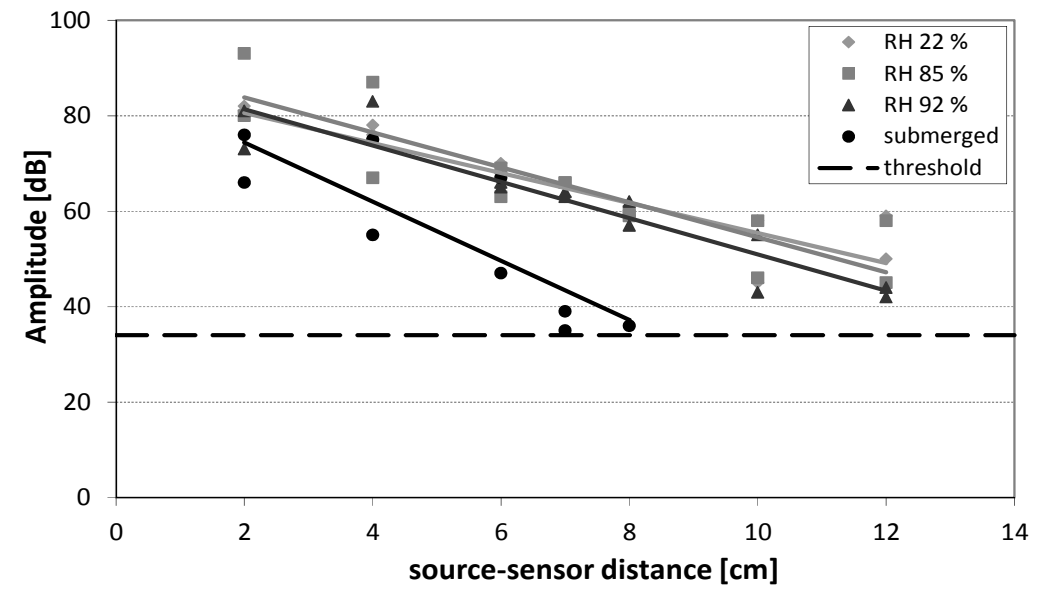

Fig. 7. Attenuation profile for ultrasonic waves in Diestian ferruginous sandstone. 
Above results indicate that in case ultrasonic test methods are applied for on-site quality and degradation assessment, the moisture level should be considered since it largely influences the obtained UPV and attenuation values, especially in case of lower quality ferruginous sandstone. Dedicated additional study is necessary to control the boundary conditions related to practical application (moisture levels and inhomogeneous moisture distributions, size effects, test setup and direct versus indirect measurements).

\section{2 mineralogical analysis}

To characterize the mineralogical composition of the samples, petrographic analysis on thin sections and quantitative X-ray diffraction (XRD) was performed.

\section{Microscopy on thin sections}

After impregnation with epoxy, thin sections with a thickness of $\pm 30 \mu \mathrm{m}$ are made and analyzed with a Zeiss polarizing microscope equipped with a Nikon Coolpix 4500 digital camera. A digital image is presented in Fig. 8.

(a)

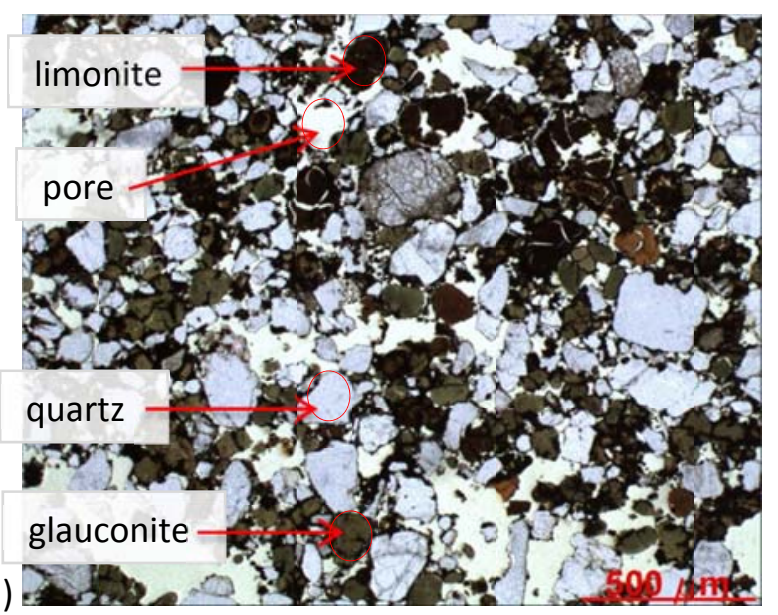

(b)

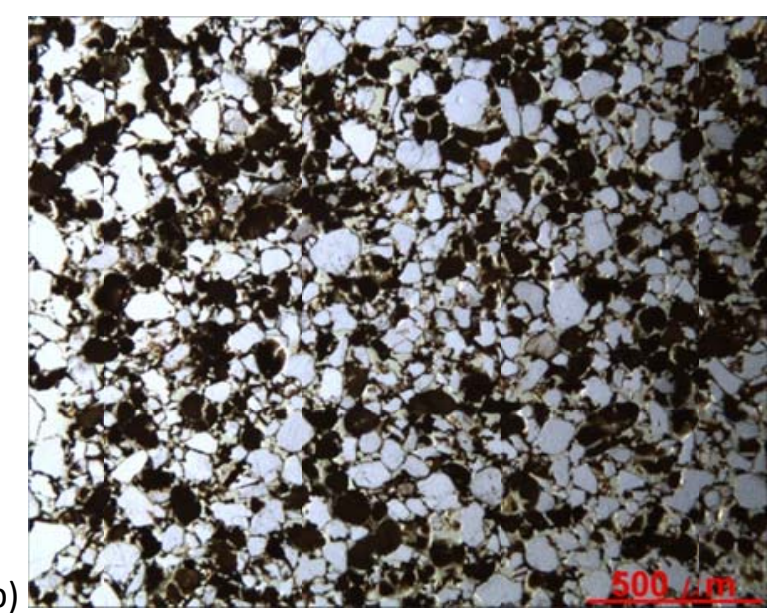


(c)

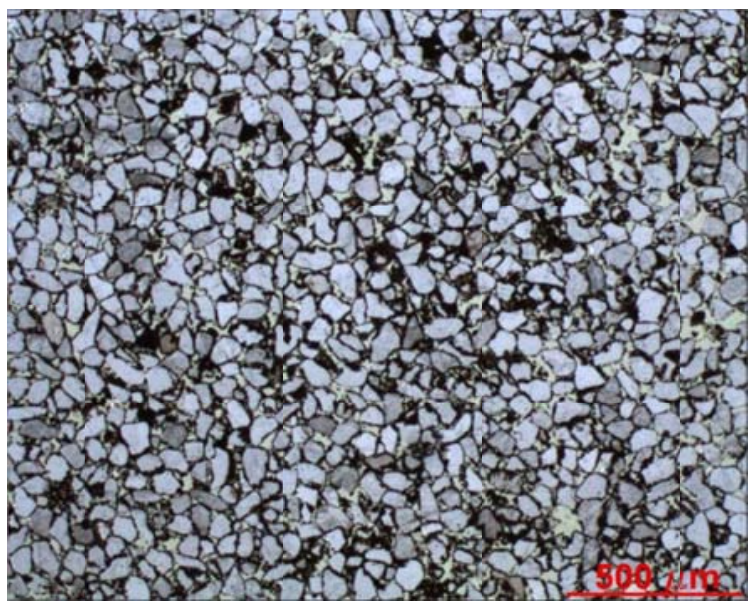

Fig. 8. Visualization of thin section of low quality (a) and high quality (b) Diestian ferruginous sandstone and Brusselian ferruginous sandstone (c).

The Brusselian ferruginous sandstone contains mainly quartz (white grains) and limonite (dark brown). The latter consists of iron oxides and hydroxides and functions as a binder. The limonite is present as a small layer around the quartz grains and in between the quartz grains. Pores (yellow) are small and well distributed. The Diestian ferruginous sandstones show a more heterogeneous composition, with a large amount of glauconite (green), especially for the low quality sandstone (Fig 8a). In case of the higher quality Diestian ferruginous sandstone (Fig 8b), the glauconite is more oxidized and therefore not green in color. Limonite (dark brown) is also present in Diestian ferruginous sandstone, but is more coagulated and appears to act less as a binder. The grain size distribution of the quartz grains is less homogeneous and larger pores are present, causing a less coherent structure, especially in case of the low quality Diestian sandstone. In comparison with the low quality variant, the higher quality Diestian ferruginous sandstone has a more homogeneous structure and smaller, more distributed pores which is in accordance with the open porosity measurements presented in Section 4.1.

\section{XRD analysis}

To quantify the difference in mineralogical composition between the sandstone types, an X-ray powder diffraction analysis was performed with a Phillips PW1830 diffractometer equipped with a BraggBrentano geometry setup. Powdered ferruginous sandstones were mixed with an internal standard and milled using a McCrone micronizing mill [24]. Samples were subsequently side-loaded into aluminum measurement holders to ensure minimal preferred orientation. XRD scans were recorded from $5-75^{\circ} 2 \theta$ with a step size of $0.02^{\circ}$, each step lasting 2 seconds. Data interpretation and mineral quantification was performed using Topas Academic [25].

The quantitative analysis was performed for the most relevant minerals in the ferruginous sandstones and the results are presented in Table 4 . Since this is an expensive and time consuming procedure, two 
tests were performed for each ferruginous sandstone type, so the results of the Brusselian sandstone are the average of two tests and the low and high quality Diestian ferruginous sandstone each represent one XRD test. The data clearly indicate the difference between the ferruginous sandstone types.

\begin{tabular}{|l|c|c|c|c|c|c|c|}
\hline & & & \multicolumn{2}{|c|}{ Limonite } \\
& Quartz & $\begin{array}{c}\text { K- } \\
\text { feldspar }\end{array}$ & Goethite & $\begin{array}{c}\text { Lepido- } \\
\text { crocite }\end{array}$ & $\begin{array}{c}\text { Illite- } \\
\text { Smectite }\end{array}$ & Glauconite & Kaolinite \\
\hline $\begin{array}{l}\text { Low quality Diestian } \\
\text { ferruginous sandstone }\end{array}$ & $66 \%$ & $1 \%$ & $8 \%$ & $1 \%$ & $2 \%$ & $22 \%$ & $<1 \%$ \\
\hline $\begin{array}{l}\text { High quality Diestian } \\
\text { ferruginous sandstone }\end{array}$ & $64.5 \%$ & $1.5 \%$ & $7 \%$ & $0 \%$ & $1 \%$ & $25 \%$ & $<1 \%$ \\
\hline $\begin{array}{l}\text { Brusselian ferruginous } \\
\text { sandstone }\end{array}$ & $90 \%$ & $0 \%$ & $6 \%$ & $0 \%$ & $1.5 \%$ & $2.5 \%$ & $<1 \%$ \\
\hline
\end{tabular}

Table 4: Mineralogical composition of Diestian and Brusselian ferruginous sandstone as obtained by quantitative XRD analysis.

The quartz content is clearly higher for Brusselian ferruginous sandstone. Quartz has a high hardness (7 on the Mohs scale) and can be seen as the aggregate in the inner structure, contributing to the ferruginous sandstone's compressive strength. Although all tested ferruginous sandstones contain similar amounts of Goethite and Lepidocrocite, it was seen in the microscopic analysis that this limonite material is more coagulated in case of Diestian ferruginous sandstone and therefore functions less as a binder. It can also be clearly observed that the Brusselian ferruginous sandstone has a much lower claycontent. It is very likely that the glauconite is part of the clay-fraction, since the presence of other clay minerals (2:1 Al-clays) is limited. There is no distinct difference between the results of the high and low quality Diestian ferruginous sandstone, which can partly be ascribed to the fact that only one sample was tested for each type, which makes it difficult to differentiate between both qualities. In addition, it can be concluded that in our case, the distribution of pores and minerals and the difference in grain size account for the difference in mechanical properties between the low and high quality Diestian sandstones, rather than the relative differences in mineralogical composition.

In conclusion, the petrographic analysis clearly identifies the differences in mineralogy between the sandstone samples and the results will be related to the different mechanical behavior of the ferruginous sandstones. It was also observed that the Diestian ferruginous sandstone has a significantly larger clay content, which is relevant for its behavior in wet conditions. The mechanical behavior of the ferruginous sandstone in dry and wet conditions will be discussed in the next section. 


\section{3 mechanical testing}

The sandstones' mechanical behavior was investigated by means of compressive tests to quantify standard mechanical properties and by advanced creep and relaxation tests to investigate the influence of moisture ingress on the material's time-dependent deformation behavior.

\section{Compressive tests}

Uniaxial compressive tests were carried out in a displacement-controlled setup ( $1 \mathrm{~mm} / \mathrm{min}$ ) while deformations were monitored with two vertical and two horizontal linear variable differential transducers (LVDTs). An overview of the test results is presented in Table 5 and Fig. 9.

In previous research, attempts were made to quantify the decrease in strength of ferruginous sandstone under saturated conditions, but no statistically significant result was obtained due to the large scatter on the strength values [5]. To overcome this problem and take into account the small amount of test material available, specimens with similar composition were applied for the current dry and wet compressive tests. For each test on a dry specimen, a related test on a saturated specimen which originated from the same drilled core was performed. This results in a 'paired' test, which still has restricted statistical significance but enables to observe the strength decrease in a more reliable manner.

From Table 5, a strength reduction of $40-60 \%$ is found for saturated samples. A proportionally higher strength decrease can be observed for specimens with an initially lower compressive strength. Typical stress-strain curves obtained during the compressive tests are presented in Fig. 9, with the dry specimens presented with solid lines and the paired, wet specimens in dashed lines. From these graphs, a strength reduction can clearly be observed for the saturated specimens.

\begin{tabular}{|l|c|c|c|}
\hline $\begin{array}{l}\text { Compressive strength } \\
{\left[\mathrm{N} / \mathrm{mm}^{2}\right]}\end{array}$ & $\begin{array}{c}\text { Low quality Diestian } \\
\text { ferruginous sandstone }\end{array}$ & $\begin{array}{c}\text { High quality Diestian } \\
\text { ferruginous sandstone }\end{array}$ & $\begin{array}{c}\text { Brusselian ferruginous } \\
\text { sandstone }\end{array}$ \\
\hline Dry specimen & $1.69(\# 2)$ & $8.59(\# 1)$ & $12.09(\# 2)$ \\
\hline Saturated specimen & $0.69(\# 2)$ & $4.27(\# 1)$ & $7.23(\# 2)$ \\
\hline Decrease (dry $\rightarrow$ wet) & $59 \%$ & $50 \%$ & $40 \%$ \\
\hline
\end{tabular}

Table 5: Results of compressive tests on dry and saturated ferruginous sandstone. 


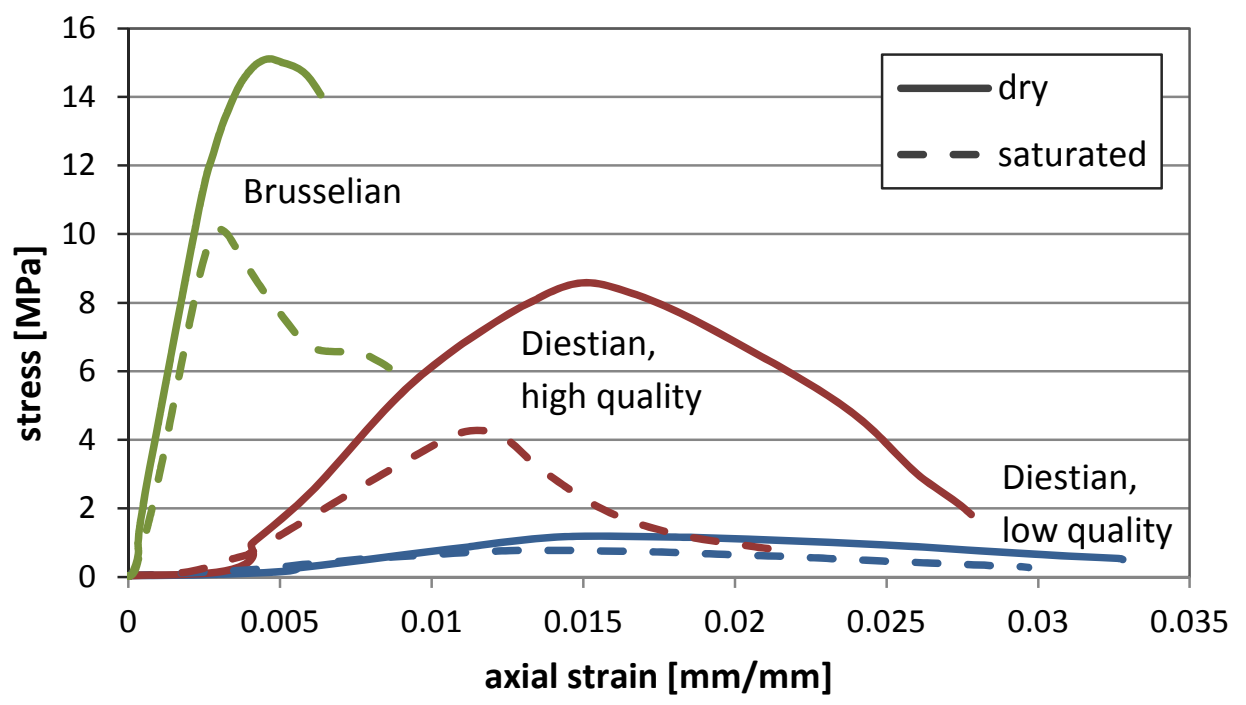

Fig. 9. Stress-strain curves obtained from uniaxial compressive tests on dry and saturated ferruginous sandstone. Results of dry samples indicated in solid lines and related saturated samples in dashed lines.

\section{Acoustic Emission (AE)-controlled creep tests}

Creep tests are performed to characterize masonry's time-dependent behavior under sustained compressive stresses $[3,5,26]$. As discussed in section 2 , moisture is likely to have an effect on timedependent deformations under constant load levels. At constant stress, creep deformations occur in three stages; after stress increase, a primary creep phase with decreasing strain rate is observed. The primary creep phase gradually shifts to the secondary creep phase with a constant strain rate, which is related to the relative stress level. At high stresses, damage increase during the secondary creep phase can accumulate to an unstable situation and a tertiary creep phase with increasing strain rate leads to failure of the masonry. Grgic and Amitrano [8] performed multistep uniaxial creep tests on porous rock (iron ore) samples and found that the addition of water during the creep tests induced an increase in acoustic emission activity and dilatant volumetric strains. They attributed these effects to a decrease in effective mean stress and subcritical stress corrosion cracking at the crack tips caused by physicochemical mechanisms induced by the water.

In the present experimental program, creep tests were only carried out on low and high quality Diestian Ferruginous sandstone. Uniaxial compressive loading was applied in cyclic steps and for each step, the stress level was sustained during a period of 15 minutes to 2 hours. For subsequent cycles, a load increase of 1 or $2 \mathrm{kN}$ was applied in comparison with the previous step and in between load cycles, the specimen was unloaded to a minimum value of 2 or $5 \mathrm{kN}$. The lower values are used for low-strength sandstone, the higher for high-strength sandstone samples. Loading and unloading stages were carried out displacement-controlled ( $1 \mathrm{~mm} / \mathrm{min}$ ), while the press would adjust constantly to sustain the given 
target load. The execution of (cyclic) stepwise creep tests to verify masonry's creep behavior is discussed in $[3,4,27]$.

When applying these rather short constant stress steps, it is very difficult to obtain a tertiary creep phase in which damage propagation becomes unstable and accumulates into creep failure. In a previous test program [4], only 1 out of 9 test specimens showed a distinct tertiary creep phase. The others failed during stress increase. To resolve this problem, the creep tests described here have been carried out as acoustic emission-controlled creep tests as this technique helps identifying when the tertiary creep phase is (almost) reached.

Acoustic emissions ( $\mathrm{AE}$ ) are high frequency elastic waves, which are emitted during local stress redistributions in the material caused by structural changes, such as crack growth $[22,28]$. These high frequency signals are recorded on the material's surface by means of piezoelectric transducers, called $\mathrm{AE}$ sensors. Since the acoustic emission technique monitors the emitted energy levels during progress of micro cracking, it is very efficient for detection of creep damage progress in masonry under sustained stresses. During the creep tests, results of online AE detection were used to decide on the duration of the constant stress step and on the amount of subsequent load increase during the next cycle. Consequently, 7 out of 8 tests showed a distinct tertiary creep phase.

The load, deformations (two vertically and one horizontally positioned LVDT) and acoustic emissions were recorded during the cyclic creep tests. Acoustic emission activity was detected by means of four AE sensors (PZT, resonance frequency of $150 \mathrm{kHz}$ ), see Fig. 10. Vacuum grease is used as a coupling agent between sensor and sandstone. The AE preamplifier gain is set to $34 \mathrm{~dB}$ and an amplitude threshold level of $34.5 \mathrm{~dB}$ is applied for triggering of $A E$ events.

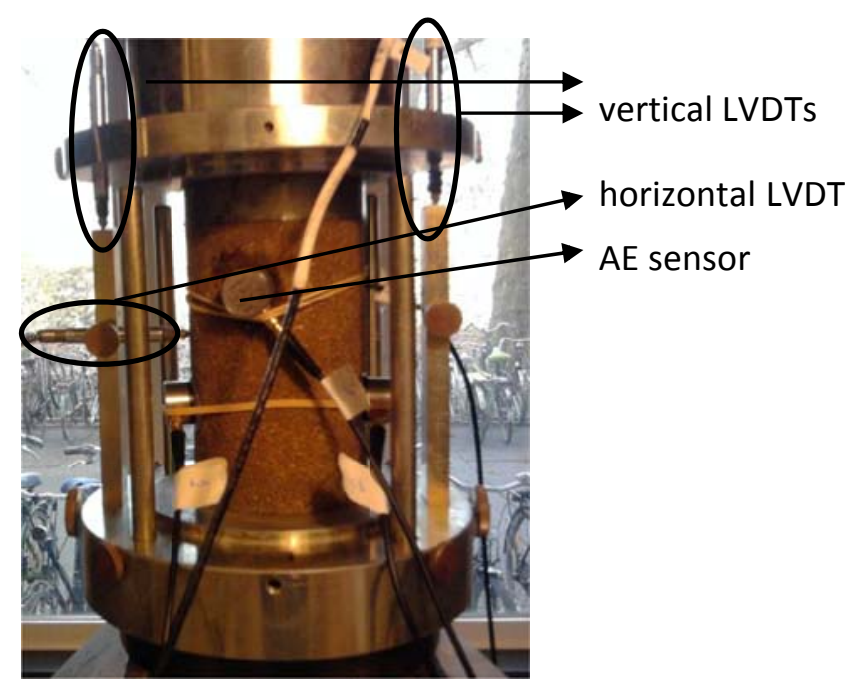

Fig. 10. Setup of uniaxial creep tests on cylindrical sandstone samples (diameter $80 \mathrm{~mm}$ ) 
A brief overview of the executed creep tests and results is presented in Table 6. Eight creep tests have been performed, of which four on high quality and four on low quality Diestian sandstone samples. Creep tests were performed on dry test specimens ( 2 and 3), specimens which were submerged in water for 30 minutes before testing and which were allowed to dry during the test ( 4 and 5 ) and specimens which were tested dry up to the last loading steps during which water was added at the base of the specimen to a height of $1.5 \mathrm{~cm}(6-9)$. Water was immediately adsorbed by the specimens to a height of several centimetres. All four specimens failed before the maximum adsorption height was reached. Specimen 1 is not mentioned in the table, as a monotonic compression test was carried out on this sample to test all sensors and verify the test setup.

It can be observed from Table 6 that the samples which were classified as good quality sandstone (specimen 2, 4, 6 and 8) clearly reached higher stresses during testing. Representative graphs of the relation between cumulative number of $A E$ events, stress and time are presented in Figs. 11-14. Primary (A), secondary (B) and tertiary creep (C) are indicated. Failure of the specimen is preceded by an increase in $A E$ activity. When water is added about 20 minutes after stress increase, the sandstone starts failing, even if the AE emission was still stable and tertiary creep was not yet reached before water addition, see Figs. 12 and 14. It was also observed that upon the addition of water to a good quality sandstone sample, AE started increasing rapidly while strains increased only slightly until failure occurred. For poor quality sandstone, upon water adsorption, AE detection and deformations started increasing both immediately. Similar conclusions were drawn for tests 6-7, see [29] for a more detailed discussion on this part of the test results and on damage localization results.

As expected, both water content and sandstone quality had a large impact on obtained strength and deformations. All sandstone samples which were subjected to a constant stress level and showed stable secondary creep (tests 6-9) suddenly became unstable and failed after a short tertiary creep phase upon water adsorption at the base of the specimen.

\begin{tabular}{|c|l|c|c|c|}
\hline $\begin{array}{c}\text { Test } \\
\text { specimen }\end{array}$ & Test condition & $\begin{array}{c}\text { estimated sample } \\
\text { quality }\end{array}$ & $\begin{array}{c}\sigma_{\max } \\
{[\mathrm{MPa}]}\end{array}$ & $\begin{array}{c}\text { duration last loading } \\
\text { step [min] }\end{array}$ \\
\hline 2 & dry & good & 12.1 & 52 \\
\hline 3 & dry & bad & 2.8 & 122 \\
\hline 4 & submerged for 30 min. & good & 8.0 & 5 \\
\hline 5 & submerged for 30 min. & good & 9.4 & 5 (after water addition) \\
\hline 6 & addition of water in final step & bad & 3.2 & 5 (after water addition) \\
\hline 7 & addition of water in final step & good & 7.2 & $\begin{array}{c}105 \text { (after water } \\
\text { addition) }\end{array}$ \\
\hline 8 & $\begin{array}{l}\text { addition of water before } \\
\text { observation of increased } \\
\text { secondary creep rate }\end{array}$ & bad & 3.2 & 5 (after water addition) \\
\hline 9 & $\begin{array}{l}\text { addition of water before } \\
\text { observation of increased } \\
\text { secondary creep rate }\end{array}$ & & \\
\hline
\end{tabular}

Table 6: Overview of experimental creep tests on Diestian ferruginous sandstone 


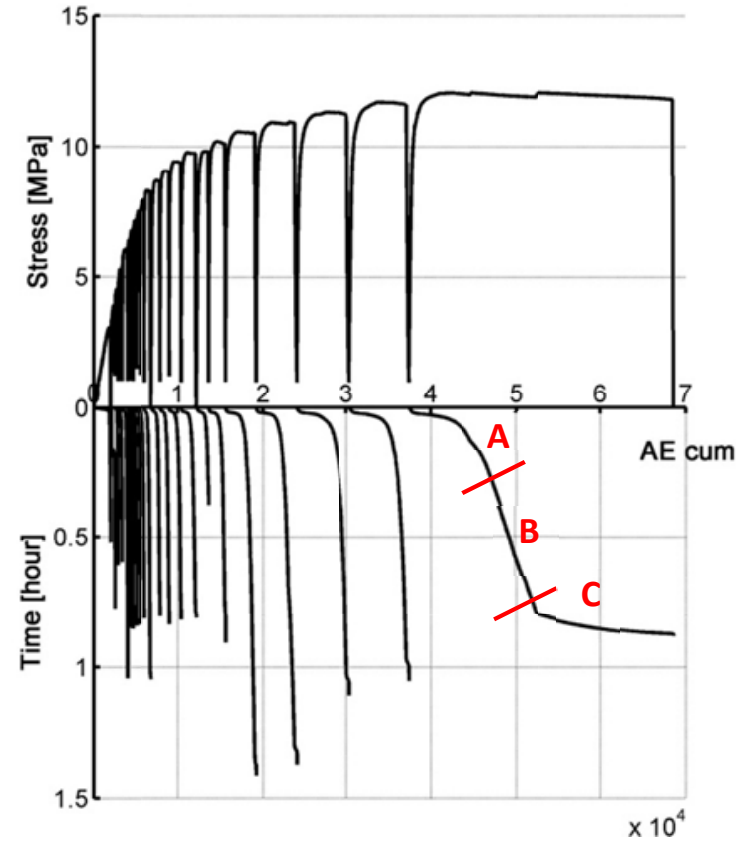

Fig. 11. Relation between cumulative number of $A E$ events, stress and time for creep test 2 (dry; good quality Diestian ferruginous sandstone)

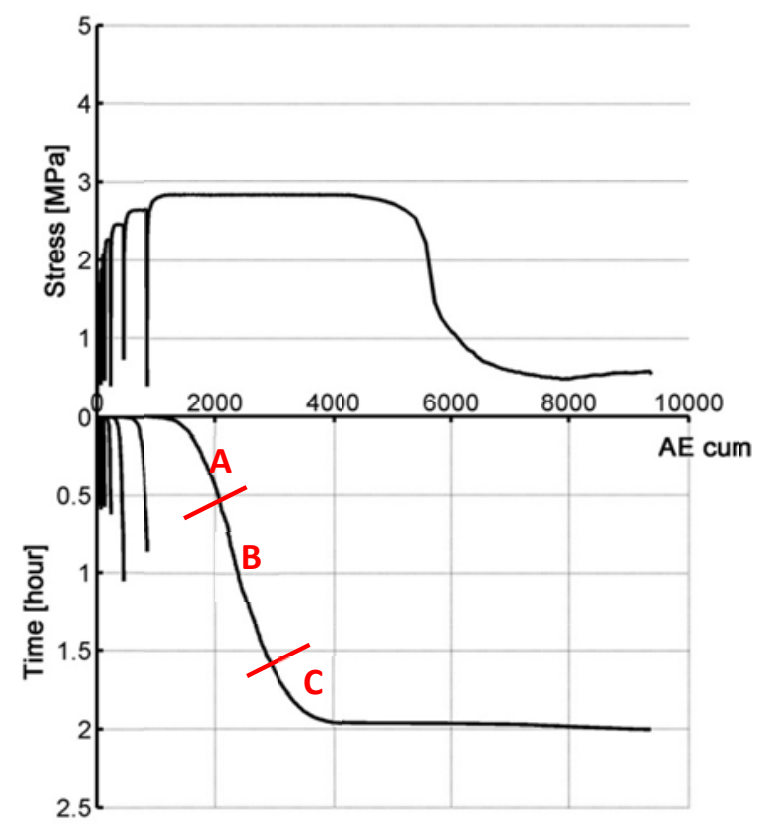

Fig. 13. Relation between cumulative number of AE events, stress and time for creep test 3 (dry; poor quality Diestian ferruginous sandstone)

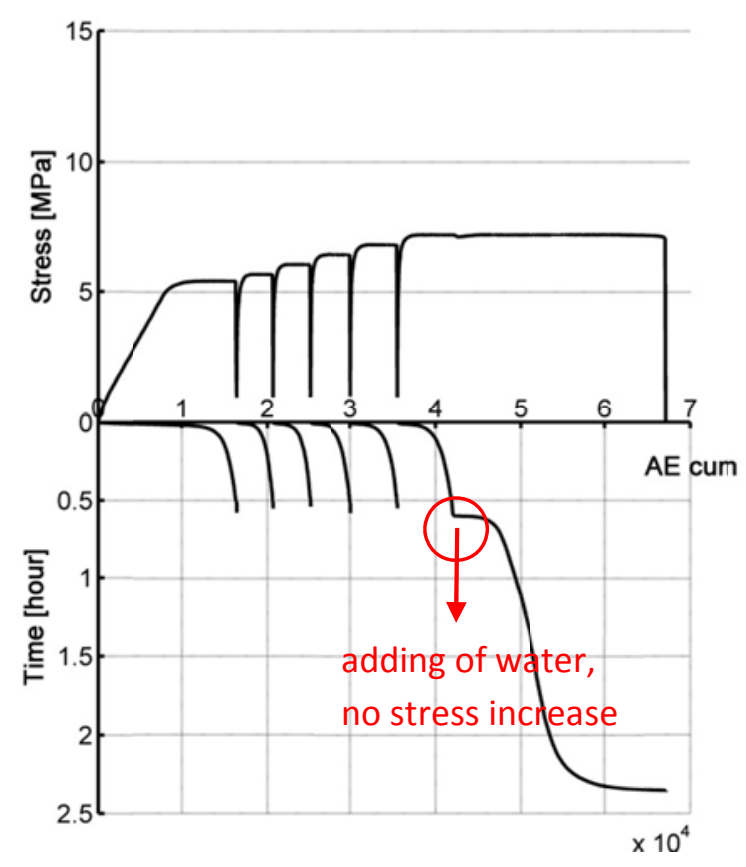

Fig. 12. Relation between cumulative number of AE events, stress and time for creep test 8 (good quality; water addition instead of stress increase)

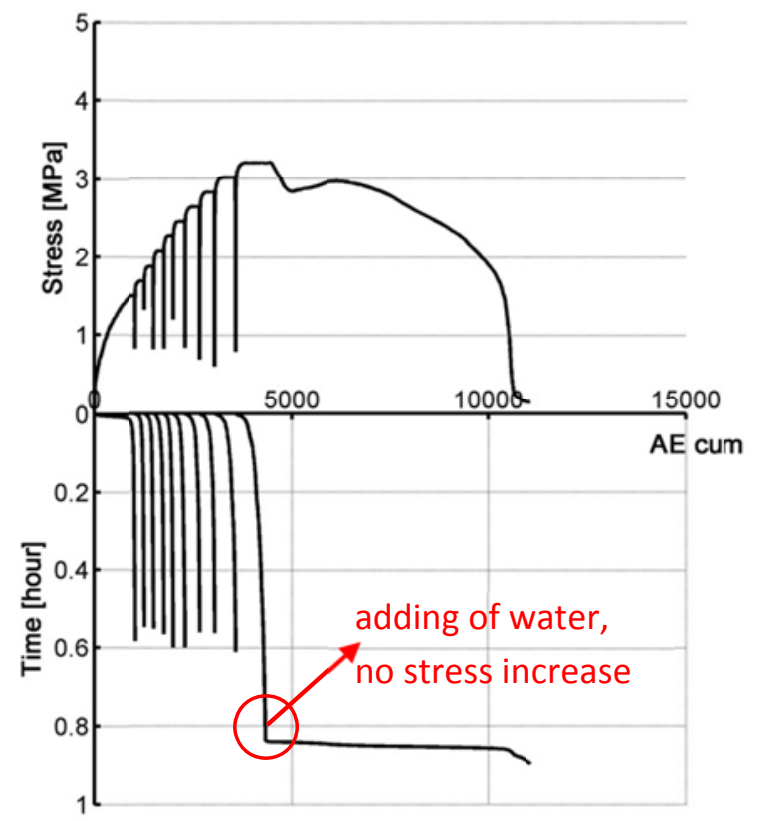

Fig. 14. Relation between cumulative number of AE events, stress and time for creep test 9 (poor quality; water addition instead of stress increase) 


\section{X-ray microfocus computed tomography}

$\mathrm{X}$-ray microfocus computed tomography (microCT) is a non-destructive observation technique which allows to visualize the inner structure of a non-transparent specimen, based on the attenuation of Xrays. It can be used to study the internal structure of porous building materials such as mortar, bricks and sandstone [30,31]. In medical applications, a scanner-detector system rotates around an object while in applications of microfocus $\mathrm{CT}$ or microCT, the object rotates and the scanner-detector system remains immobile. The raw data consist of $2 \mathrm{D}$ projection images. These images are used as input for reconstruction software, which composes a 3D array of density values. The 3D result can be used to produce horizontal or vertical sections and analyse 2D and 3D morphological parameters. The resolution limit of the system is in the order of micrometres (microCT) down to nanometres (nanoCT) for advanced and expensive systems. For the microCT tests reported here, a resolution of $7.8 \mu \mathrm{m}$ was achieved on a SkyScan 1172 system.

Aim of the microCT tests was to visualize the inner structure of the ferruginous sandstone during cracking and investigate the different failure modes in dry and wet conditions. Therefore, small cylindrical sandstone samples (diameter $\pm 10 \mathrm{~mm}$, height $14-15 \mathrm{~mm}$ ) were scanned at different stages of a compression test. To enable stress application during scanning, a small, transparant compression cell was fabricated in polyetherimide (PEI). This compression cell allows to apply a constant compressive deformation while performing the scans, see Fig. $15 \mathrm{a}$ and b. The load is applied with a mechanical press, until a target stress level is reached. The target stress level depends on the sample type (low or high strength expected) and scan number (as indicated in Fig. 15c). Then the cap of the compression cell is fixed. The moment at which the force is transferred from the mechanical press to the compression cell is marked by a small bud sudden force decrease on the digital output of the mechanical press. After fixation of the cap of the compression cell, the compressive strains within the sandstone specimen remain constant and a microCT scan is performed. This procedure is repeated until failure of the specimen. Since the strains are kept constant during scanning, this test is a stepwise relaxation test. The aim is to perform 4 scans for each specimen: in the initial state, during elastic deformation, just before and just after reaching the maximum load level. A representative stress-strain graph is indicated in Fig. 15c. Each scan has a duration of approximately 1.5 hour, resulting in a duration of at least 6 hours for each test. A total of 13 microCT tests were performed; at least two dry and two saturated samples for different types of ferruginous sandstone.

The applied loading procedure introduces some error in the registration of the load levels and the indicated stresses can thus not be seen as accurate quantitative values. In addition, the small size of the specimens and roughness of the surface at the loaded ends also introduce inaccuracies in the estimated average compressive stress. Therefore, a precise quantification of the acting stresses was not aimed for. The specimen size was chosen as small as possible to ensure a sufficiently high scan resolution, but could not be reduced any further as the volume would no longer be representative for low quality Diestian ferruginous sandstone. This sandstone type contains grains and coagulated fragments having a size up to $1 \mathrm{~mm}$ which is only 10 times smaller than the chosen specimen diameter. 


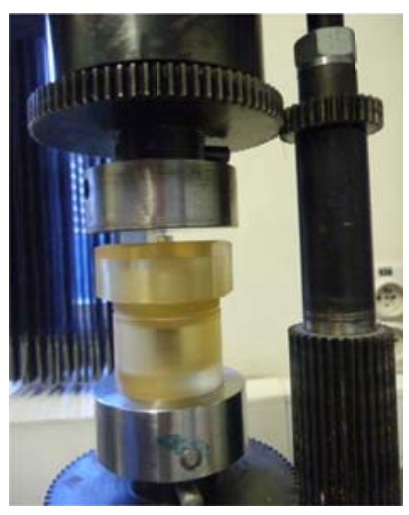

(a)

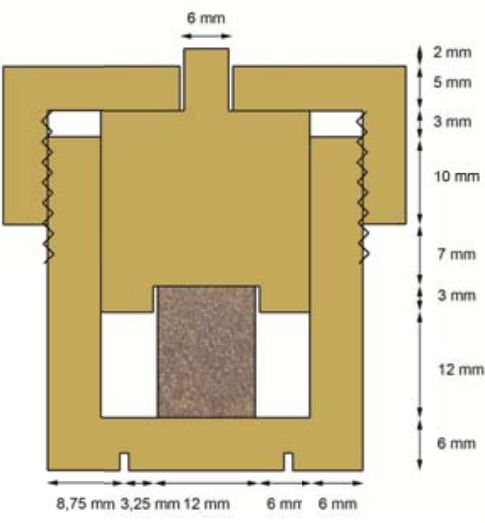

(b)

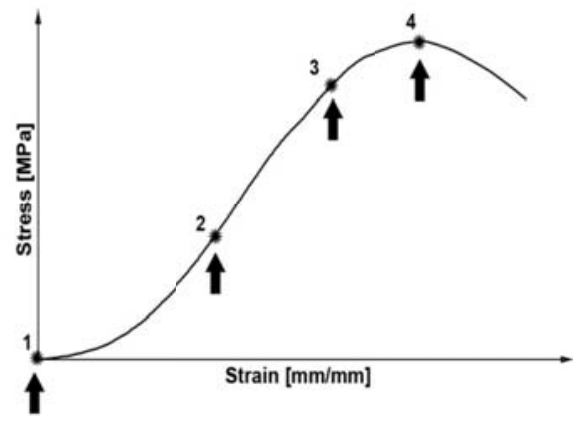

(c)

Fig. 15. View and dimensions of compression cell ( $a$ and $b$ ) and indication of targets for execution of the scans on a representative stress-strain curve (c).

As a result of the microCT, horizontal slices were obtained which show the inner structure of the ferruginous sandstone samples during the stepwise compression tests. A magnification of such horizontal slice is presented in Fig. 16. The mineralogical components, which were identified during the microscopic study can be traced back on these images by taking into account the relative density of the constituents. The densities are related to the grayscale, ranging from black (pores) to nearly white (high density particles such as limonite).
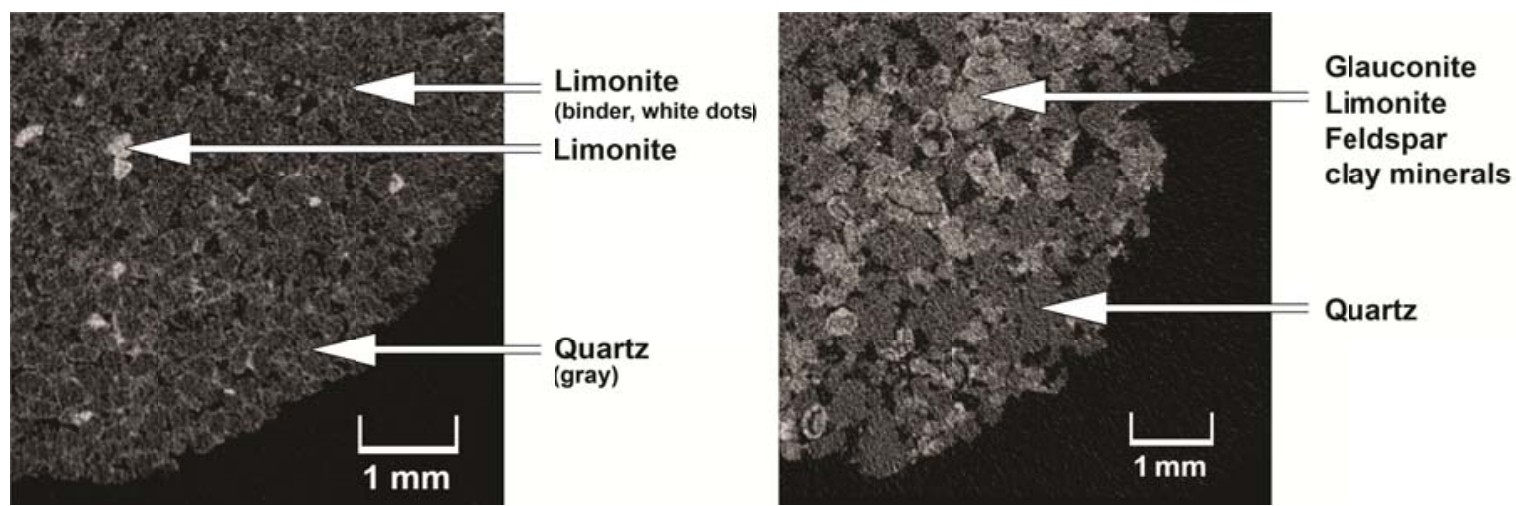

Fig. 16. Indication of different mineralogical constituents in Brusselian (left) and low quality Diestian (right) ferruginous sandstone.

An overview of the microCT test results is presented in Figs. 17-18. A representative stress - axial strain curve is given for a stepwise compressive test on a dry and saturated Brusselian ferruginous sandstone sample (Fig. 17a and b). In these graphs, the small stress increase during fixation of the cap of the load cell and stress losses due to relaxation during scanning are not shown, since they could not be recorded with the applied setup. The horizontal slices, obtained from the subsequent scans during the compressive tests are presented for a dry as well as for a saturated sample and an indicative porosity 
value is indicated below each image. The scan moments are also indicated on the stress-strain graphs. Similar results are presented for low quality Diestian ferruginous sandstone in Fig. 18.

The results indicate that the saturated samples show a less brittle behavior with a more progressive crack growth smeared out over a longer time period, compared to the dry test specimens. This can be observed from comparison of the stress-strain curves and from the microCT images. On the scans of the saturated samples, the crack initiation and growth can be observed in an early stage during the compression test. In some cases, the large pores or inhomogeneities along the crack path could already be observed in the non-loaded specimens. Besides these observations, no distinct difference was found between the behavior of the dry and saturated samples on the micro scale.

The porosity values indicated below the scan images are determined for 11 subsequent slices (the one shown and 5 above and below) and they are relative values, since the greyscale threshold which differentiates between pore space and particles has to be chosen manually. In addition, only pores larger than 8 micrometers can be detected due to the resolution of the scans, and the small samples do not contain very large macro pores such as were observed for the larger size samples of low quality Diestian ferruginous sandstone. For these reasons, the porosity values indicated here for the low quality Diestian sandstone are lower than the open porosity which was determined in Section 4.1. When performing a relative comparison between porosity values of subsequent steps during a compression test, a similar behavior is observed for all samples: the value initially decreases in the second scan (compaction) and increases markedly for the fourth scan (dilatation). In case cracks are already formed in the second or third scan, an increase in porosity value is also observed here (see Fig. 17a-b and 18b). This procedure can thus be applied for detection of crack formation and dilatation onset in small samples, provided that a sufficient amount of scans is made during the stepwise compression test. In our case, for 3 out of 9 tests on Brusselian ferruginous sandstone, the porosity value started increasing for the same scan on which crack initiation could be visually observed. For the other 6 tests, porosity increase was observed at the scan stage just before visual observation. In case of low quality Diestian ferruginous sandstone, porosity increase and visual crack detection coincided for all 4 tests.

In general, the scan resolution was not sufficient to observe the very initiation of micro cracks and the behavior of the clay minerals. However, quartz grains $(0.1-1 \mathrm{~mm})$, coagulated clay fragments and relatively large pores could be distinguished on the microCT results. On Figs. 18 b1-4, it can clearly be observed that the intergranular fracture passes between the quartz grains but splits the coagulated glauconite-limonite-clay particle (white circle on Fig. 18 b3). 


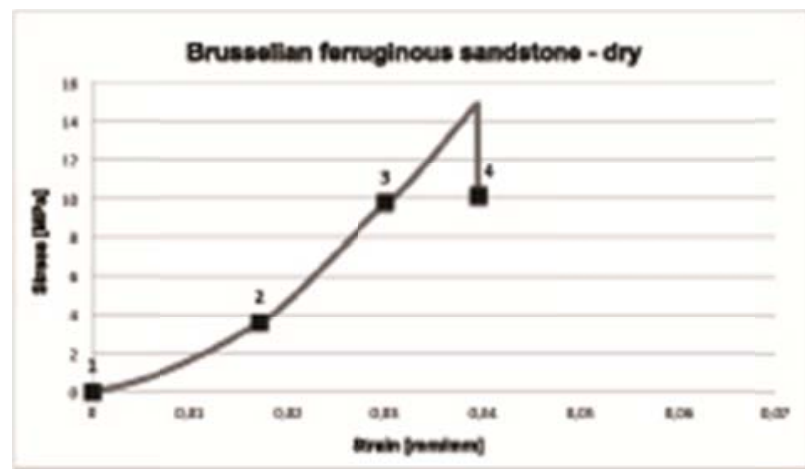

(a)

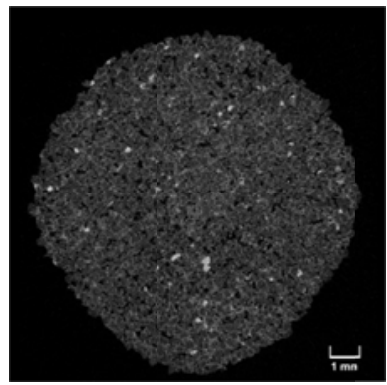

a1.) $22.7 \%$

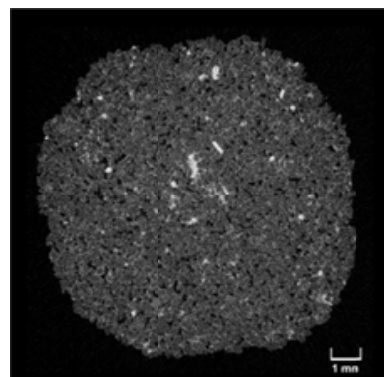

b1.) $20.8 \%$

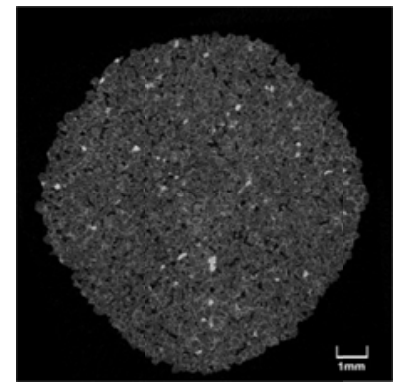

a2.) $18.0 \%$

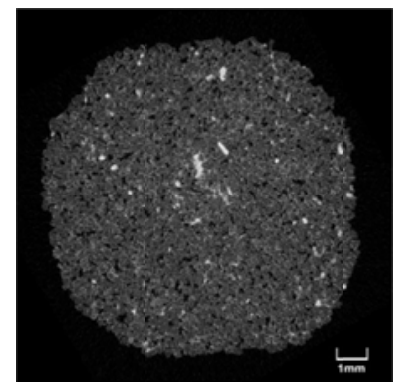

b2.) $20.3 \%$

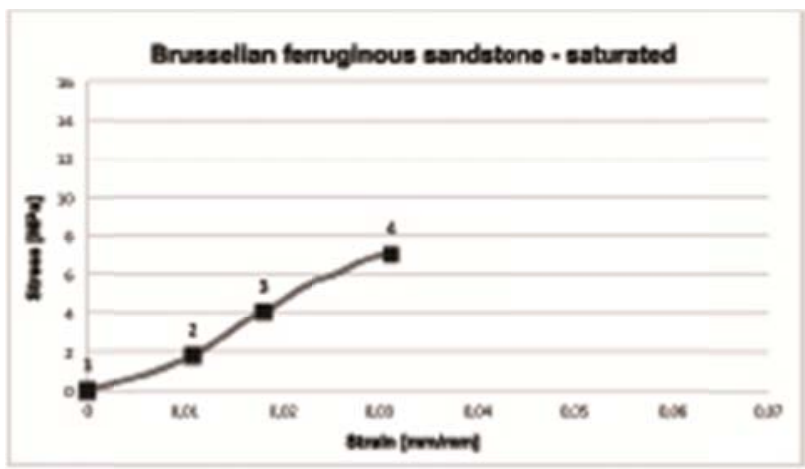

(b)

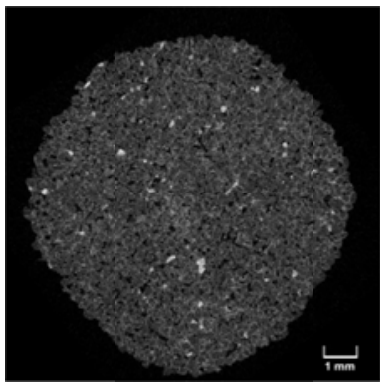

a3.) $20.9 \%$

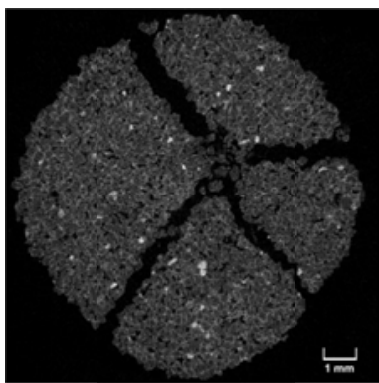

a4.) $31.6 \%$

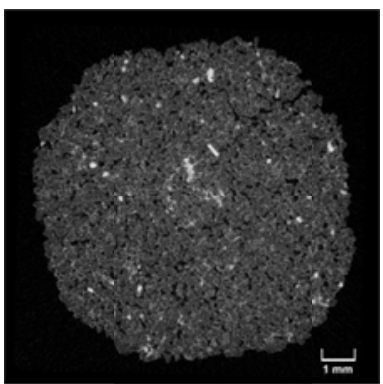

b3.) $22.3 \%$

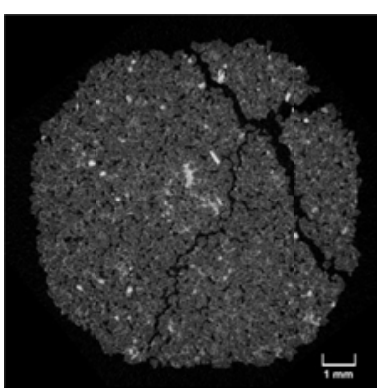

b4.) $36.3 \%$

Fig. 17. Results of microCT on Brusselian ferruginous sandstone: stress-strain graph of dry (a) and saturated (b) sample. Horizontal slices obtained by microCT on a dry (a1-4) and saturated (b1-4) sample, with indication of 2D porosity (\%). Scan moments are indicated on the stress-strain graphs. 


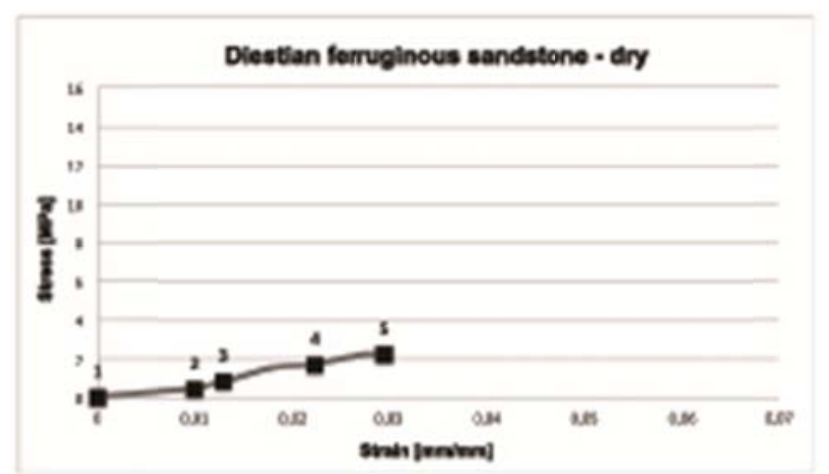

(a)

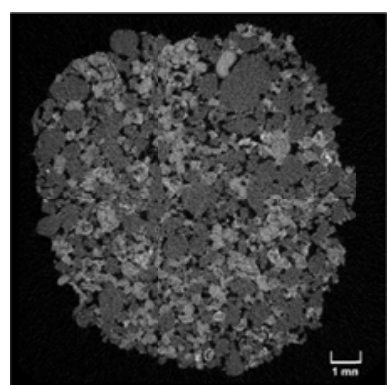

a1.) $27.6 \%$

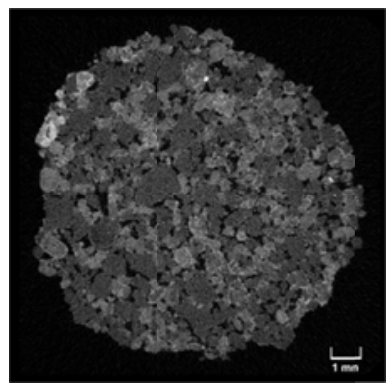

b1.) $23.5 \%$

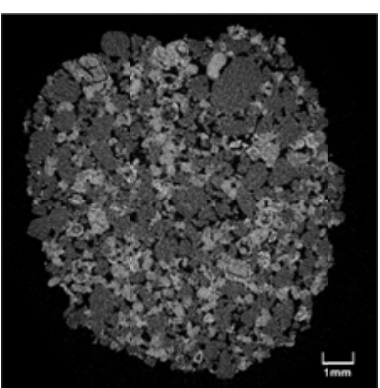

a3.) $26.2 \%$

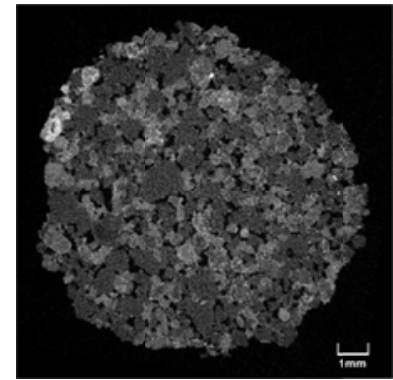

b2.) $23.1 \%$

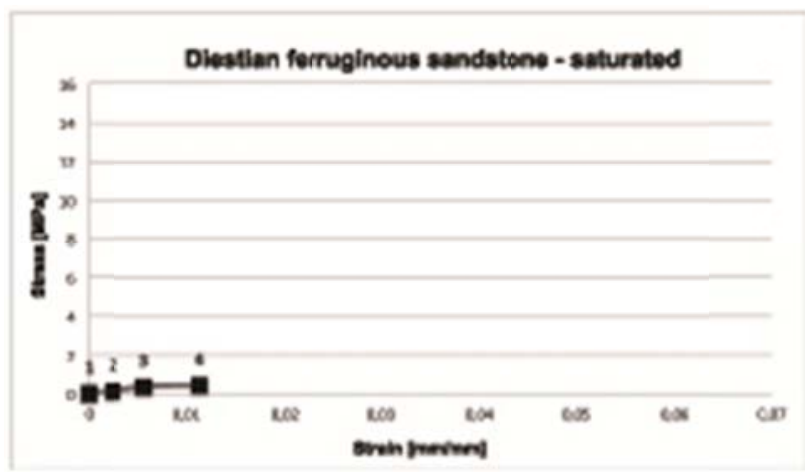

(b)

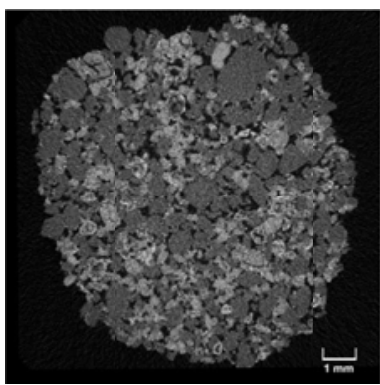

a4.) $25.4 \%$

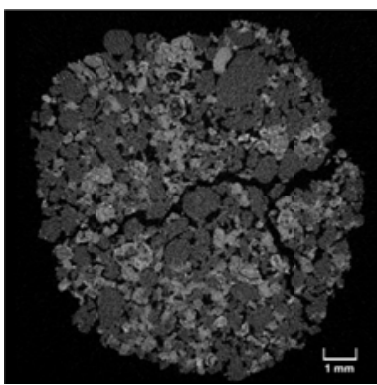

a5.) $38.5 \%$

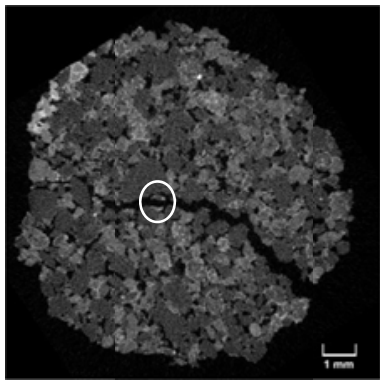

b3.) $26.1 \%$

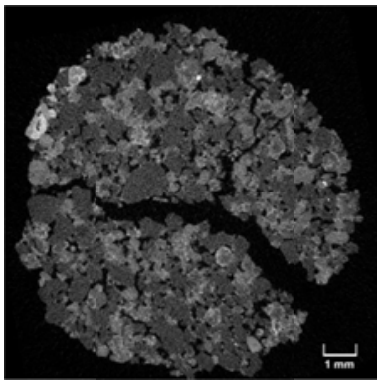

b4.) $35.0 \%$

Fig. 18. Results of microCT on low quality Diestian ferruginous sandstone: stress-strain graph of dry (a) and saturated (b) sample. Horizontal slices obtained by microCT on a dry (a1-4) and saturated (b1-4) sample, with indication of 2D porosity (\%). Scan moments are indicated on the stress-strain graphs.

\section{Discussion of combined results and conclusions}

To understand the influence of moisture on the mechanical behavior of ferruginous sandstone, a multiscale experimental investigation was carried out, including non-destructive testing, mineralogical analysis and mechanical testing. This combined study provided in-depth information on the composition and behavior of each sample type. The multi-scale investigation also enabled to obtain valuable results 
to investigate a complex issue based on a limited amount of test samples. In this section, the results of the different tests will be combined to obtain a general framework for the assessment of moisture influence. This also highlights the importance of the applied multi-scale methodology.

The non-destructive testing helped to initially characterize the samples. Fig. 19 presents the combined results of the ultrasonic tests and compressive tests on dry and saturated ferruginous sandstone samples. In this graph, results on Diestian as well as Brusselian sandstone are combined. The saturated samples have lower ultrasonic pulse velocity and compressive strength, resulting in a shift in the linear regression curve. Since moisture has a larger influence on the ultrasonic pulse velocity of the lower quality samples, the slope of the regression line also changes. It should however be noticed that the UPV values presented in this graph are obtained on test specimens with a relatively small size and can therefore not be transferred to on-site applications without prior re-calibration as explained in Section 4.1. To set up quantitative models with confidence intervals and apply these data for on-site quality assessment, more experimental data are needed, especially regarding the influence of moisture (which cannot be controlled on-site), specimen size and sensor setup. The obtained graphs indicate the importance of taking into account the moisture levels of the investigated sample (in lab or in situ) if nondestructive tests are performed for strength assessment purposes.

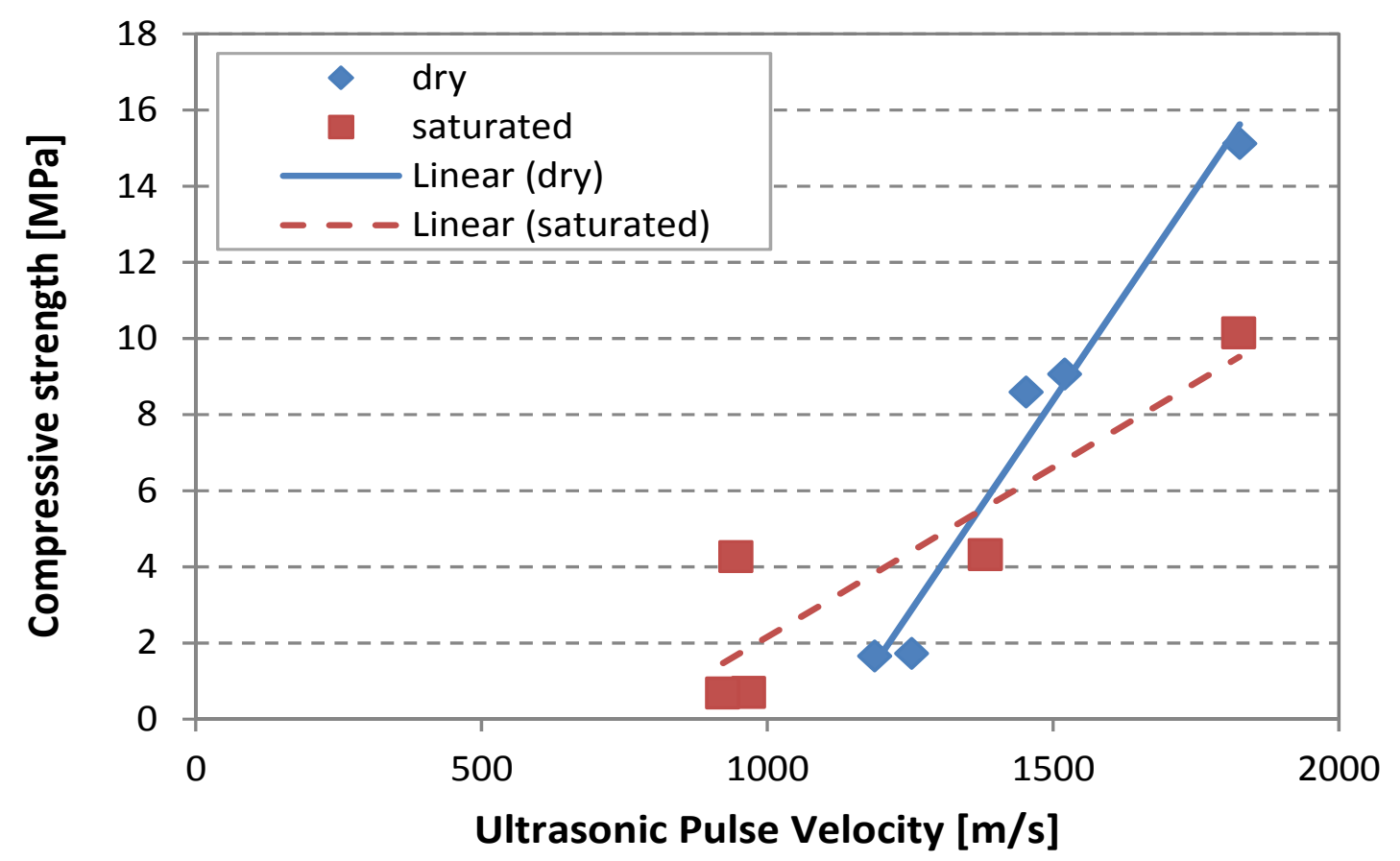

Fig. 19. Relation between ultrasonic pulse velocity and compressive strength for dry and saturated ferruginous sandstone samples. 


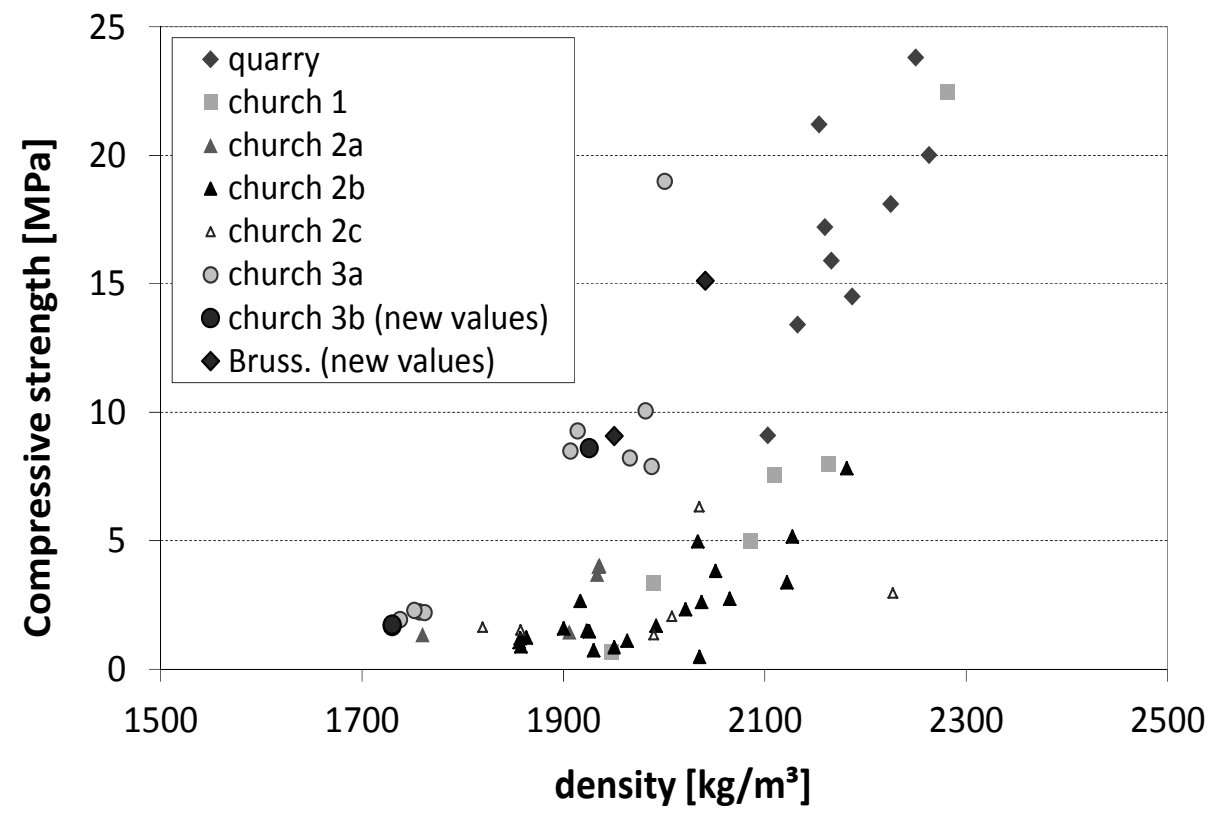

Fig. 20. Relation between strength (in dry conditions) and density of Diestian ferruginous sandstone. Diestian sandstone specimens of tests discussed in this paper are from church 3 (St. Willibrordus church in Meldert [4]). Present results on Brusselian ferruginous sandstone samples are also included (Bruss.)

In Fig. 20, the compressive strength and apparent density results obtained in the present work are combined with previous experimental results, relating the strength and density of Diestian ferruginous sandstone [29]. This graph is based on results of former investigations on Diestian ferruginous sandstone, acquired from sampling at three different historical monuments and a small quarry. It can be noticed that a relatively small range of density values $\left(1700-2300 \mathrm{~kg} / \mathrm{mm}^{3}\right)$ is related to a large variation in strength (1-25 MPa). A distinct positive correlation can be observed between both quantities, as was also observed between strength and UPV values.

The results of the petrographic analysis were applied to explain the difference in strength properties between both qualities Diestian ferruginous sandstone and Brusselian ferruginous sandstone respectively. It was shown that the relative amounts of mineralogical constituents (quartz and limonite) and the overall porosity, as well as the pore and grain size distribution have an important effect on the material's strength. Results of the mineralogical analysis also proved to be useful for identification of the different components on the microCT scan images and enhanced interpretation of the observed damage pattern.

Results of the mechanical tests on two different time scales (compressive tests and creep tests) indicated that the effect of moisture is larger on the lower quality ferruginous sandstones, as the strength reduction is larger and creep failure occurs almost immediately upon water uptake. During the compressive creep tests, the acoustic emission technique proved very efficient for on-line evaluation of 
damage progress and control of the stress path followed during the tests. Remarkably, all sandstone samples who were subjected to a constant stress level and showed stable secondary creep suddenly became unstable and failed after a short tertiary creep phase upon water adsorption at the base of the specimen. Addition of water had a similar effect on the specimen's macroscopic behavior as an increase of the stress level. Compressive tests on small scale specimens in combination with microCT enabled the observation of crack growth (intergranular fracture progress) in dry and saturated samples. Lower strength and less frictional resistance was observed for the saturated samples, as cracks were initiated at lower stress levels and fracture occurred in a less brittle manner.

The larger impact of moisture on the mechanical strength and ultrasonic pulse velocity of Diestian ferruginous sandstone in comparison with Brusselian ferruginous sandstone can be explained by the presence of clay, as observed during the mineralogical study. The Brusselian sandstone contains a majority of quartz and negligible amounts of clay components. The low quality, as well as the high quality Diestian ferruginous sandstone was found to contain a large amount of glauconite (up to $25 \%$ ). The difference between low and high quality Diestian sandstone could only be explained by the pore and grain size distribution and continuity of the binder (limonite), resulting in better consolidated material with a stronger inner structure in case of higher quality Diestian ferruginous sandstone.

To conclude, the application of a multi-scale methodology enabled to set up a general framework for understanding and assessing the influence of moisture on the mechanical behavior of ferruginous sandstone.

\section{Acknowledgements}

The authors gratefully acknowledge the financial support of The Research Foundation - Flanders (FWO) for the postdoctoral grant of Els Verstrynge. Also the work of J. Hulsmans, S. Konings, E. Bourel, G. Hechtermans and G. Pyka is gratefully acknowledged.

\section{References}

[1] Gullentops F. L'origine des collines du Hageland (in French). Bulletin de la Société belge de géologie / Bulletin van de Belgische vereniging voor geologie 1957; 66:81-85.

[2] Bos K. The Saint Peter's church of Langdorp, an example of early Gothic church architecture in the valley of the river Demer; A historical and architectural outline with an in-depth study of its typical building material: the ferruginous sandstone of Northern Belgium. PhD Thesis, in Centre for the Conservation of Historic Towns and Buildings. Centre for the Conservation of Historic Towns and Buildings, KU Leuven: Leuven. 1989.

[3] Binda L., ed. Learning from Failure - Long-term behaviour of heavy masonry structures. Advances in Architecture. Vol. 23. WIT Press: Southampton. (2008).

[4] Verstrynge E., Schueremans L., Van Gemert D. Creep and failure prediction of Diestian ferruginous sandstone: modelling and repair options. Construction and Building Materials 2012; 29:149-157. 
[5] Verstrynge E. Long-term behaviour of monumental masonry constructions: modelling and probabilistic evaluation. PhD Thesis. Civil Engineering Department, K.U.Leuven: Leuven. 2010.

[6] NBN EN 772-1:2000 Methods of test for masonry units - Part 1: Determination of compressive strength.

[7] Witzany J., Cejka T., Zigler R. The effect of moisture on significant mechanical characteristics of masonry. Engineering Structures and Technologies 2010; 2(3):79-85.

[8] Grgic D., Amitrano D. Creep of a porous rock and associated acoustic emission under different hydrous conditions. Journal of Geophysical Research-Solid Earth 2009; 114(B10201).

[9] Van Eeckhout E.M. Mechanisms of Strength Reduction Due to Moisture in Coal-Mine Shales. International Journal of Rock Mechanics and Mining Sciences 1976; 13(2):61-67.

[10] Han G., Dusseault M.B., Cook J. Quantifying Rock Capillary Strength Behavior in Unconsolidated Sandstones (78170-MS), in SPE/ISRM Rock Mechanics Conference. Society of Petroleum Engineers Inc.: Irving, Texas. 2002.

[11] Erguler Z.A., Ulusay R. Water-induced variations in mechanical properties of clay-bearing rocks. International Journal of Rock Mechanics and Mining Sciences 2009; 46(2):355-370.

[12] Anzani A., Binda L., Roberti G.M. A numerical interpretation of long-term behaviour of masonry materials under persistent loads. Structural Studies of Historical Buildings IV - vol 1:

Architectural Studies, Materials and Analysis 1995:179-186.

[13] van Zijl G.P.A.G. Computational modelling of masonry creep and shrinkage. PhD Thesis. Delft University of technology: Delft. 2000.

[14] Van Campenhout D. Verleden en toekomst van de exploitatie van ijzerzandsteen uit het Diestiaan als bouwsteen, een geologische studie (in Dutch), in Earth and Environmental Sciences Department. Earth and Environmental Sciences Department, KULeuven: Leuven. 2009.

[15] EN 12504-4 : 2004 Testing concrete: Determination of ultrasonic pulse velocity.

[16] ASTM D2845 1995 Standard test method for laboratory determination of pulse velocities and ultrasonic elastic constants of rock. American Society for Testing Materials.

[17] Panzera T.H., Christoforo A.L., Cota F.P., Borges P.H.R., Bowen C.R. Ultrasonic pulse velocity evaluation of cementitious materials, in Advances in Composite Materials - Analysis of Natural and Man-Made Materials and Structures, Tesinova P., Editor. InTechOpen. 2011. p.

[18] Vasconcelos G., Lourenço P.B., Alves C.S.A., Pamplona J. Prediction of the mechanical properties of granites by ultrasonic pulse velocity and Schmidt hammer hardness, in 10th North Americal Masonry Conference. The Masonry Society: St. Louis, USA. 2007. p. 980-991.

[19] Ohdaira E., Masuzawa N. Water content and its effect on ultrasound propagation in concrete the possibility of NDE. Ultrasonics 2000; 38(1-8):546-552.

[20] Bellopede R., Manfredotti L. Ultrasonic sound test on stone: comparison of indirect and direct methods under various test conditions, in Heritage Weathering and Conservation, Fort R., et al., Editors. Taylor \& Francis/Balkema. 2006. p. 539-546.

[21] Winkler K.W., Murphy W.F. Acoustic Velocity and Attenuation in Porous Rocks, in Rock Physics \& Phase Relations: A Handbook of Physical Constants, Ahrens T.J., Editor. American Geophysical Union: Washington D. C. 1995. p. 20-34.

[22] Grosse C.U., Ohtsu M., eds. Acoustic emission testing - basics for research - applications in civil engineering. Springer. (2008).

[23] Gist G.A. Fluid Effects on Velocity and Attenuation in Sandstones. Journal of the Acoustical Society of America 1994; 96(2):1158-1173.

[24] Srodon J., Drits V.A., McCarty D.K., Hsieh J.C.C., Eberl D.D. Quantitative X-ray diffraction analysis of clay-bearing rocks from random preparations. Clays and Clay Minerals 2001; 49(6):514-528. 
[25] Snellings R., Machiels L., Mertens G., Elsen J. Rietveld refinement strategy for quantitative phase analysis of partially amorphous zeolitized tuffaceous rocks. Geologica Belgica 2010; 13(3):183195.

[26] Tomor A.K., Verstrynge E. A joint fatigue-creep deterioration model for masonry with acoustic emission based damage assessment. Construction and Building Materials 2013; 43:575-588.

[27] Binda L., Schueremans L., Verstrynge E., Ignoul S., Oliveira D.V., Lourenco P.B., et al. Long term compressive testing of masonry - test procedure and practical experience, in 6th International Seminar on Structural Analysis of Historical Constructions, D'Ayala D., Fodde E., Editors: Bath. 2008. p. 1345-1355

[28] Wevers M. Listening to the sound of materials: Acoustic emission for the analysis of material behaviour. NDT \& E International 1997; 30(2):99-106.

[29] Verstrynge E., Konings S., Wevers M. The influence of moisture on creep behaviour of sandstone assessed by means of acoustic emission in 8th International Conference on Structural Analysis of Historical Constructions, Jasienko J., Editor: Wroclaw, Poland. 2012. p. 2573-2581.

[30] Cnudde V., Dewanckele J., Boone M., de Kock T., Boone M., Brabant L., et al. High-Resolution XRay CT for 3D Petrography of Ferruginous Sandstone for an Investigation of Building Stone Decay. Microscopy Research and Technique 2011; 74(11):1006-1017.

[31] Landis E.N., Nagy E.N. Three-dimensional work of fracture for mortar in compression. Engineering Fracture Mechanics 2000; 65(2-3):223-234. 